\title{
INTERNATIONAL TRADE AND \\ FACTOR MOBILITY: \\ AN EMPIRICAL INVESTIGATION
}

\author{
Linda S. Goldberg
}

Michael W. Klein

Working Paper 7196

http://www.nber.org/papers/w7196

\author{
NATIONAL BUREAU OF ECONOMIC RESEARCH \\ 1050 Massachusetts Avenue \\ Cambridge, MA 02138 \\ June 1999
}

This paper was prepared for the Festschrift in Honor of Robert Mundell. The views expressed in this paper are those of the individual authors and do not necessarily reflect the position of the Federal Reserve Bank of New York or the Federal Reserve System. We thank Alan Winters for comments on an earlier draft. Jenessa Gunther and Kevin Caves provided excellent research assistance. All opinions expressed are those of the authors and not those of the National Bureau of Economic Research.

(C) 1999 by Linda S. Goldberg and Michael W. Klein. All rights reserved. Short sections of text, not to exceed two paragraphs, may be quoted without explicit permission provided that full credit, including (C) notice, is given to the source. 
International Trade and Factor Mobility:

An Empirical Investigation

Linda S. Goldberg and Michael W. Klein

NBER Working Paper No. 7196

June 1999

JEL No. F31, F3, F4

\section{ABSTRACT}

Foreign Direct Investment (FDI) has been growing rapidly, at a pace far exceeding the growth in international trade. Thus, a full understanding of the relationship between trade in goods and FDI is important for obtaining a complete picture of the extent and sources of international linkages. We investigate whether FDI serves as a complement to trade or a substitute for trade based on the effects identified by the Rybczynski theorem whereby an increase in a factor of production used intensively in one sector affects production both in that sector and in other sectors. Using detailed data on bilateral capital and trade flows between the United States and individual Latin American countries, we examine the linkages between FDI into particular sectors of Latin American economies and the net exports of those and other manufacturing sectors. We find that FDI from the United States can lead to significant, and varied, shifts in the composition of activity in many Latin American countries and across many manufacturing industries.

Linda S. Goldberg

Federal Reserve Bank of NY

Research Department

33 Liberty St

New York, NY 10045

and NBER

Linda.Goldberg@ny.frb.org
Michael W. Klein

Fletcher School of Law and Diplomacy

Tufts University

Medford, MA 02155

and NBER

mklein@tufts.edu 


\section{Introduction}

It is a notable achievement to develop an economic model that provides a framework for understanding and analyzing important economic issues of the day. It is an even more striking achievement to develop an economic model that addresses an issue that will be of central importance in the future. In the 1950s, a time when cross-border capital movements were largely stymied by government regulations, Robert Mundell published a series of papers studying the implications of capital mobility. Today's central paradigms for studying events in a world characterized by vast flows of capital across national boundaries draw on Mundell's analysis that foresaw such a world. An examination of the linkages between international capital movements, domestic production and international trade is especially timely today, given the massive and volatile capital flows to emerging markets observed through the 1990s.

Mundell studied capital mobility in a variety of frameworks. He is best known for the Mundell-Fleming model which analyzes the effect of portfolio capital movements on the efficacy of monetary and fiscal policy. Monetary authorities today are intimately aware of the central lessons of this model. Less well-known, but increasingly relevant, are issues considered in Mundell's work on the implications of physical capital mobility for international trade. In a world of significant growth of both international direct investment and international trade, this work raises important considerations for policy-makers who are concerned with understanding trade and direct investment linkages among countries.

In "International Trade and Factor Mobility" (1957), Mundell demonstrates the substitutability of international trade and factor mobility. In the context of the HeckscherOhlin-Samuelson model, perfect factor mobility across sectors within an economy provides a tendency for commodity-price equalization, even in the absence of international trade in goods. This result complements the Stolper-Samuelson theorem, which demonstrates the tendency for factor-price equalization as a consequence of goods trade, even in the absence of international trade in factors. International factor mobility also serves as a substitute for trade in another sense in the Heckscher-Ohlin-Samuelson (H-OS) model, since an increase in the volume of factor movements can decrease the volume of trade. 
Subsequent theoretical work has demonstrated that models which diverge from the standard H-O-S assumptions can result in complementarity, rather than substitutability, between factor trade and goods trade (Wong 1986). There are a variety of ways this subsequent work differs from Mundell's original contribution, including allowances for differences in technologies across countries (Kemp 1966, Jones 1967, Purvis 1972, Svensson 1984, and Markusen and Svensson 1985), introduction of production taxes, monopoly market structure, external economies of scale or factor market distortions (Markusen 1983) and permitting foreign capital to promote domestic development (Schmitz and Helmberger 1970). In all of these cases, an increase in international direct investment may promote greater international trade.

Understanding the relationship between trade in goods and trade in factors is important for obtaining a complete picture of international linkages. For example, it is often the case that the amount of international trade undertaken by a country serves as a proxy for its level of "openness" or, in a bilateral context, as a measure of the international linkages between two countries. Mundell's analysis implies that focusing on trade as a proxy for openness may be misleading when international capital flows are significant. Empirically, it is important to consider whether this bias is significant and systematic in a particular direction.

Another key reason for understanding these linkages arises in the aftermath of the currency and financial crises of the 1990s. If capital inflows to a country are large, but also can abruptly change course, important real consequences can ensue. In Latin America, in Asia, or elsewhere, even exogenous reversals in foreign capital availability can lead to a redistribution of productive factors within a country. The availability of investment funds and new physical capital can have important consequences for the future structure of a country's trade and the welfare of its citizens.

The broad challenge posed by the theoretical and policy arguments can only be resolved through careful analytical and empirical studies. Recent empirical research in this area includes work by Collins, O'Rourke and Williamson (1997), who studied the historical link between labor mobility and trade, and our own work on the response of exports and imports of selected Latin American and Southeast Asian countries to direct 
investment from the United States and Japan (Goldberg and Klein 1998). Collins, O'Rourke and Williamson found little evidence of substitutability between labor movement and trade. We found some evidence of complementarity between capital flows and bilateral trade, especially in the Asian region: direct investment from Japan to Southeast Asian countries significantly increased the bilateral exports and imports of those countries with Japan. We found no evidence of significant links between capital flows and bilateral trade, however, between Latin American countries and either Japan or the United States, or between the United States and Southeast Asian countries.

In this paper we provide a motivating theoretical model, followed by a detailed empirical study of the effects of direct investment flows on levels of international trade. We present the first empirical analysis, to our knowledge, of this relationship at a sectoral level. Specifically, we study how the net exports of specific manufacturing sectors of eight Latin American countries (Argentina, Brazil, Chile, Colombia, Ecuador, Mexico, Peru, and Venezuela) respond to direct investment from the United States into those specific sectors, as well as into other manufacturing and non-manufacturing sectors of their economies. We demonstrate empirically the varied direction and levels of response of sectoral trade volumes to direct investment across manufacturing sectors and across countries.

Based on this detailed empirical evidence, we conclude that the theoretical debate is justified. In Argentina, where investments into manufacturing industries have been concentrated in Food-related industries or Chemical industries, the net exports of these industries have expanded (despite these industries remaining net importers overall), without significant detriment to other manufacturing industries. In Brazil and Venezuela, FDI into particular manufacturing industries - flows that have been concentrated in Chemicals, Machinery and Transportation Equipment - have been associated with expanded net import positions by these industries. Foreign investment into Wholesale \& Retail Trade worsened the net export positions of manufacturing industries in Mexico and Columbia (suggesting that this FDI facilitated Latin imports), but improved the net export positions in Brazilian manufacturing industries. Our detailed examination of the 
experience of individual industries, using cross-country and time-series data, does not suggest strong or systematic linkages between sectoral trade and FDI in Latin America.

\section{Direct Investment in Sector-Specific Capital and Trade}

II A. Overview. To set the stage for our empirical analysis, in this section we review the main distinctions between general equilibrium models that find that factor mobility and trade are substitutes, versus those models that find that they are complements. We then present a simple version of the Rybczynski theorem to highlight the role of sector-specific capital. Our objective is use the theoretical exposition to motivate our empirical tests for sectoral trade volumes and foreign direct investment linkages, allowing both for direct effects on trade of foreign capital inflows into a sector and for spillovers effects from inflows into other sectors.

In these general equilibrium models, the relative returns to factors and the level of production and trade are jointly determined. Typically, models differ in their predictions about the relationship between factor movements and trade volumes because of differences in assumptions about production, which lead to differences in the relative returns to factors. Across models, however, the manner in which the change in a factor endowment affects the production of each good in the economy is similar. The basis of this relationship is the Rybczynski theorem, which then drives the association between factor flows and trade volumes.

We illustrate the Rybczynski-based association between capital flows and trade volumes in the context of two types of models: in the first, countries differ in their endowments of factors but have identical production technologies (a Heckscher-OhlinSamuelson style model). In the second, production technologies are different in the two countries (a Ricardian style model). Basic forms of these models include two goods and two factors -- labor and capital. In this setting, the Rybczynski theorem states that, given

the prices of goods, an inflow of capital leads to an increase in the level of production of the good which uses capital relatively intensively, and a decrease in the level of production of the good which uses labor relatively intensively. These changes in production have direct implications for trade volumes and, in fact, will be the sole source of changes in 
trade volumes under the assumption of homothetic and identical preferences in each country.

Mundell studied the relationship between factor flows and trade in a H-O-S model. He considered a situation where a prohibitively-high tariff on imports shuts off trade and raises the return to capital in the country where it is the relatively scarce factor. This leads to a capital inflow to that country and, through the Rybczynski effect, an increase in the production of the capital-intensive good (which had been the imported good before the tariff was put in place) and a decrease in the production of the labor-intensive good (which had been the export). Capital inflows continue until relative factor endowments in the two countries are identical.

If the tariff were then removed, there would be no trade in goods. The reason is that the initial basis for trade in this model, autarky differences in relative factor endowments and the accompanying differences in relative goods prices, has been eliminated through factor flows. Factor flows can give rise to commodity price equalization, much as in the standard $\mathrm{H}-\mathrm{O}-\mathrm{S}$ model goods trade gives rise to factor price equalization. More broadly, in a model of this nature, an increase in the volume of factor flows causes a decrease in the volume of trade. Factor flows substitute for trade flows.

An alternative result can arise in a Ricardian model in which countries have different technologies. For example, suppose each of two countries has the same labor productivity but one country enjoys higher capital productivity. The country with the higher capital productivity will export the capital-intensive good. When capital is internationally mobile, it will seek its highest returns and thus flow to the high capitalproductivity country. Through the Rybczynski effect, these capital inflows increase the production of the capital intensive good (that country's export) and decrease the production of the labor intensive good (that country's import). In this simple example, factor flows complement trade flows.

\section{B. A Basic Specific - Factors Model}

A basic model provides a context for our empirical exploration of the way in which foreign direct investment to a particular sector affects the volume of exports and imports 
of that sector as well as of other sectors. There are two goods, $A$ and $B$. The factors of production include domestic and foreign capital used solely in the production of good $A$, $K_{A}$ and $F_{A}$, respectively, domestic and foreign capital used solely in the production of good $B, K_{B}$, and $F_{B}$, respectively, and labor, $L$. Labor, unlike capital, costlessly shifts from one sector to another in response to an incipient wage differential. The amount of labor used in the production of good $A$ is denoted as $L_{A}$ and the amount used in the production of good $B$ is denoted as $L_{B}$.

There are two other key assumptions in this partial-equilibrium analysis. First, domestic and foreign capital are completely sector specific. The assumption that foreign capital is sector-specific reflects the prevalent view that direct investment typically involves some active management of an asset. (This treatment contrasts with a view of portfolio investment as only requiring the bearer to passively hold the asset.) The direct management of foreign investment requires some sector-specific knowledge that makes an investor focus on a sector within which she has particular expertise.

The second key assumption is that foreign direct investment is exogenous, an assumption which makes this a partial-equilibrium exercise. This clearly runs counter to the standard modeling assumption of perfect capital mobility since it does not allow for arbitraging rates of return across sectors. ${ }^{1}$ The implication of this second assumption is that we do not endogenously determine the equalization of returns to investments across borders, or the equilibrium volume of international capital flows. ${ }^{2}$ A general equilibrium approach could accomplish this goal, but it would likely still give rise to similar qualitative results as those shown using the simple partial equilibrium setting.

Assume that production functions take the form

$$
A=f\left(K_{A}+F_{A}, L_{A}\right) \quad B=g\left(K_{B}+F_{B}, L_{B}\right)
$$

\footnotetext{
${ }^{1}$ Recent research questions the assumption of the equalization of rates of return for a variety of types of capital. Most relevant in this context is the work of Froot and Stein (1991) who model foreign direct investment with imperfect capital markets. Empirical results in their paper, as well as in research by Klein and Rosengren (1994), suggest that there is a lack of perfect capital mobility for direct investment.

${ }^{2}$ Markusen (1995) argues that there is little evidence that direct foreign investment is related to differences in factor endowments across countries or to differences in the general return to capital.
} 
where the partial derivatives with respect to labor, $\left(f_{L}, g_{L}\right)$, and capital, $\left(f_{K}, g_{K}\right)$, are positive. The cross-partial derivatives with respect to labor and capital from either foreign or domestic sources, $\left(f_{L K}, g_{L K}\right)$, also are positive. All second partial derivatives, $\left(f_{L L}, f_{K K}, g_{L L}, g_{K K}\right)$, are negative.

With labor perfectly mobile across sectors and the labor market competitive, the wage paid to labor in Sector $A, w$, is the same as the wage paid to labor in Sector $B$. The first-order conditions for profit maximization require that firms in each sector hire labor to the point where the product wage equals the marginal product of labor,

$$
\frac{w}{p_{A}}=f_{L} \quad \frac{w}{p_{B}}=g_{L}
$$

Totally differentiating each of these relationships, and dividing through by the product wage or the marginal product of labor, we obtain

$$
\begin{aligned}
& \frac{d w}{w}-\frac{d p_{A}}{p_{A}}=\left(\frac{f_{L L}}{f_{L}}\right) d L_{A}+\left(\frac{f_{L K}}{f_{L}}\right) d F_{A} \\
& \frac{d w}{w}-\frac{d p_{B}}{p_{B}}=\left(\frac{g_{L L}}{g_{L}}\right) d L_{B}+\left(\frac{g_{L K}}{g_{L}}\right) d F_{B}
\end{aligned}
$$

where $d L_{i}$ represents the change in employment in sector $i$ and $d F_{i}$ represents foreign direct investment to sector $i$. Setting $d K_{i}$ equal to zero reflects our assumption of sectorspecific domestic capital and our interest in considering the effects of FDI rather than changes in domestic capital. ${ }^{3}$ Full employment of labor ensures that $L=L_{A}+L_{B}$, where $L$ is the total amount of labor in the economy. With a constant labor force ${ }^{4}$, we have

$$
d L_{A}=-d L_{B}
$$

\footnotetext{
${ }^{3}$ The structure of production given in equation 1 implies that domestic and foreign capital are perfect substitutes within a sector.

${ }^{4}$ We could easily assume a growing labor force, an assumption which would not change our results.
} 
Wages are continuously equated across the two sectors, and, therefore, the proportionate change in wages across sectors is equal. Solving the sets of equations for the change in labor in each sector yields:

$$
\begin{aligned}
& d L_{A}=\left(\frac{f_{L K} g_{L}}{Z}\right) d F_{A}-\left(\frac{g_{L K} f_{L}}{Z}\right) d F_{B}+\left(\frac{f_{L} g_{L}}{Z}\right)\left[\frac{d p_{A}}{p_{A}}-\frac{d p_{B}}{p_{B}}\right] \\
& d L_{B}=\left(\frac{f_{L} g_{L K}}{Z}\right) d F_{B}-\left(\frac{f_{L K} g_{L}}{Z}\right) d F_{A}+\left(\frac{f_{L} g_{L}}{Z}\right)\left[\frac{d p_{B}}{p_{B}}-\frac{d p_{A}}{p_{A}}\right]
\end{aligned}
$$

where $Z=-\left(f_{L L} g_{L}+g_{L L} f_{L}\right)>0$.

These equations show that foreign direct investment to Sector $A\left(d F_{A}>0\right)$ pulls labor into that sector, reducing the labor employment in Sector $B\left(d F_{B}>0\right)$, all else equal. The implication is that a collapse of (foreign) capital in a sector leads that sector to contract employment, leaving labor to flow to the other sector. The marginal products of labor and the degree of complementarities between labor and capital in production determine the magnitudes of the worker reallocation.

There are straightforward output implications of these labor and capital adjustments. From the production functions,

$$
\begin{aligned}
& d A=f_{K} d F_{A}+f_{L} d L_{A} \\
& d B=g_{K} d F_{B}+g_{L} d L_{B}
\end{aligned}
$$

Substituting in the results from above, we obtain

$$
\begin{aligned}
& d A=\frac{f_{L}^{2} g_{L}}{Z}\left[\frac{d p_{A}}{p_{A}}-\frac{d p_{B}}{p_{B}}\right]+\left(f_{K}+\frac{f_{L K} g_{L} f_{L}}{Z}\right) d F_{A}-\frac{f_{L}^{2} g_{L K}}{Z} d F_{B} \\
& d B=\frac{g_{L}{ }^{2} f_{L}}{Z}\left[\frac{d p_{B}}{p_{B}}-\frac{d p_{A}}{p_{A}}\right]+\left(g_{K}+\frac{g_{L K} g_{L} f_{L}}{Z}\right) d F_{B}-\frac{g_{L}{ }^{2} f_{L K}}{Z} d F_{A}
\end{aligned}
$$

These equations show that sectoral output is stimulated by an increase in its relative price or by FDI into that sector; its output is decreased by FDI into the other sector. The basic intuition is that an inflow of foreign capital into a sector increases sectoral output directly, 
by providing more capital, and indirectly, by raising the marginal product of its labor and drawing workers away from the other sector. Overall, investment to one sector increases production in that sector and decreases production in the other sector, all else equal.

Returning to the issue originally considered by Mundell and others, the implication of these results is that the effects of FDI on trade volumes depend upon whether a sector was initially a net exporter or a net importer. Assuming no demand-side effects (as would be consistent with the assumption of homothetic demand), and that relative price effects are second order, an increase in production in Sector $A$ causes international trade by that sector to increase if that sector was initially a net exporter, or to decrease if that sector was initially a net importer. The converse also holds. In all these cases, direct investment into a sector should cause an increase in the net exports of that sector and a decrease in the net exports of other sectors, all else equal.

\section{Capital and Trade Flows with Latin America}

A. Data. In this section we explore the relationship between trade and FDI using detailed sectoral data on FDI inflows and trade between the United States and eight Latin American countries: Argentina, Brazil, Chile, Colombia, Ecuador, Mexico, Peru, and Venezuela ${ }^{5}$ (sources: United States Bureau of Economic Analysis Statistics on US Direct Investment Abroad and the Feenstra NBER Trade Database). The data on FDI span both manufacturing and non-manufacturing industries; the bilateral trade data spans only the manufacturing industries. The sample period for which both trade and FDI data are available is 1972 through 1994. Trade, investment, and US income series are converted into real dollar values using the United States producer price series. The GDP series for individual Latin American countries enters in the regressions as millions of real local currency units.

\footnotetext{
${ }^{5}$ In order to make the sector definitions consistent across the trade and the FDI series, we use the manufacturing decomposition delineated by the FDI numbers, i.e. with a breakdown into Food and Kindred Products, Chemicals and Allied Products, Primary and Fabricated Metals, Industrial Machinery and Equipment, Electronic and Other Electric Machinery, Transportation, and Other Manufacturing. Data also are available for FDI into non- manufacturing sectors, which are comprised of Wholesale Trade, Banking, Finance, Services, and Other Industries. These later series are somewhat less complete, since observations are sometimes not disclosed if the scale of specific investments can be traced to individual investors from the United States.
} 
Chart 1: US FDI by Region*

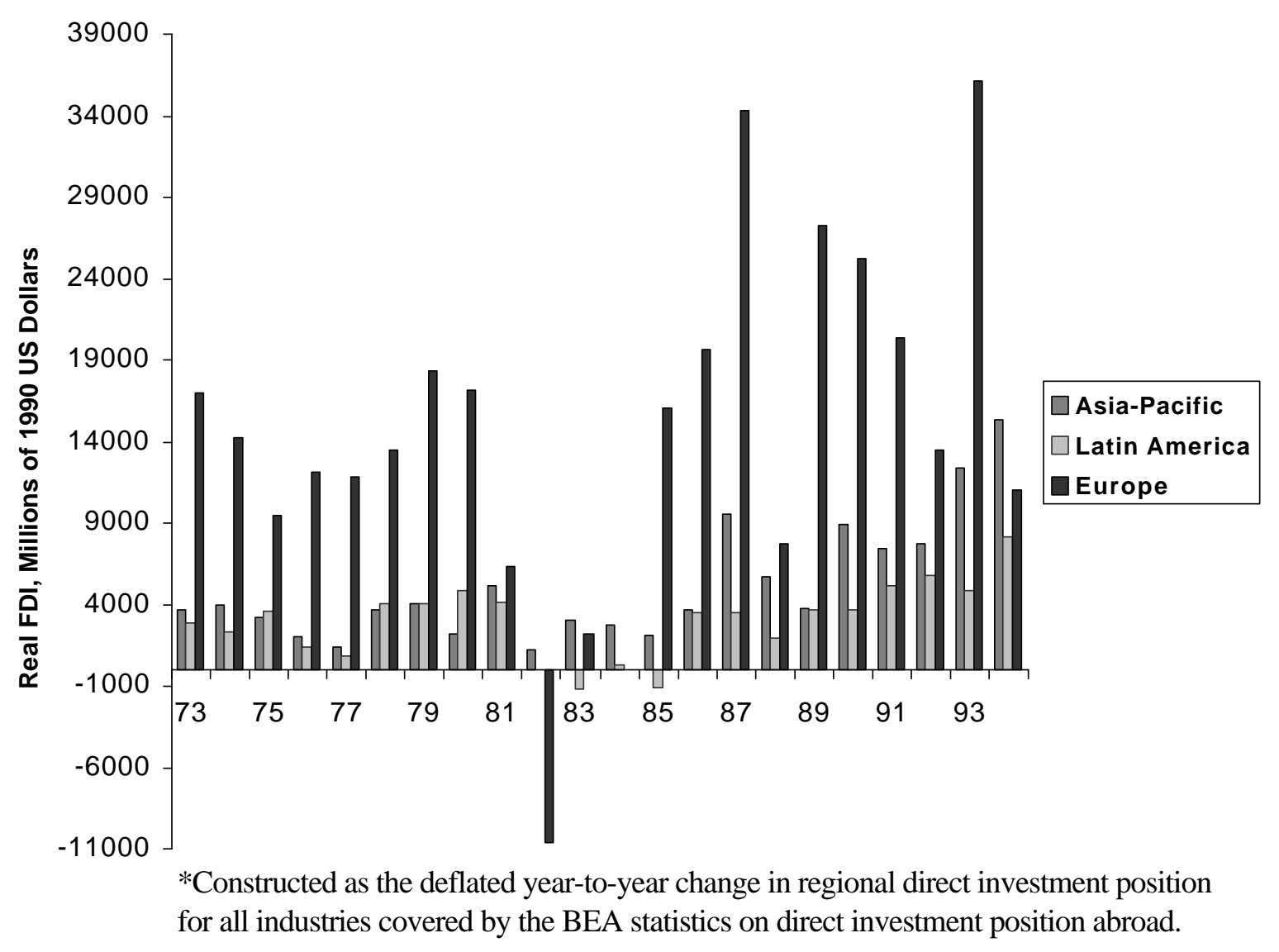

The series on FDI into Latin America from the United States, broken down by recipient country and by sector, are a construction based on the U.S. Direct Investment Position Abroad series generated by the BEA. This BEA stock series measures the yearend value of U.S. parent's equity (including retained earnings) in, and outstanding loans to, their foreign affiliates. Our FDI proxy is the change in this stock series, deflated by an annual dollar producer price index. This proxy combines direct investment capital flows plus valuation adjustments, so that FDI can be positive or negative in any period. As described by the BEA, valuation adjustments result from price changes, exchange rate changes, and other factors. Although our proxy for FDI clearly is not a perfect measure, it is the closest series we have (and most comparable across countries) for indicating annual FDI by sector. 


\section{Chart 2: Annual FDI from the US*}

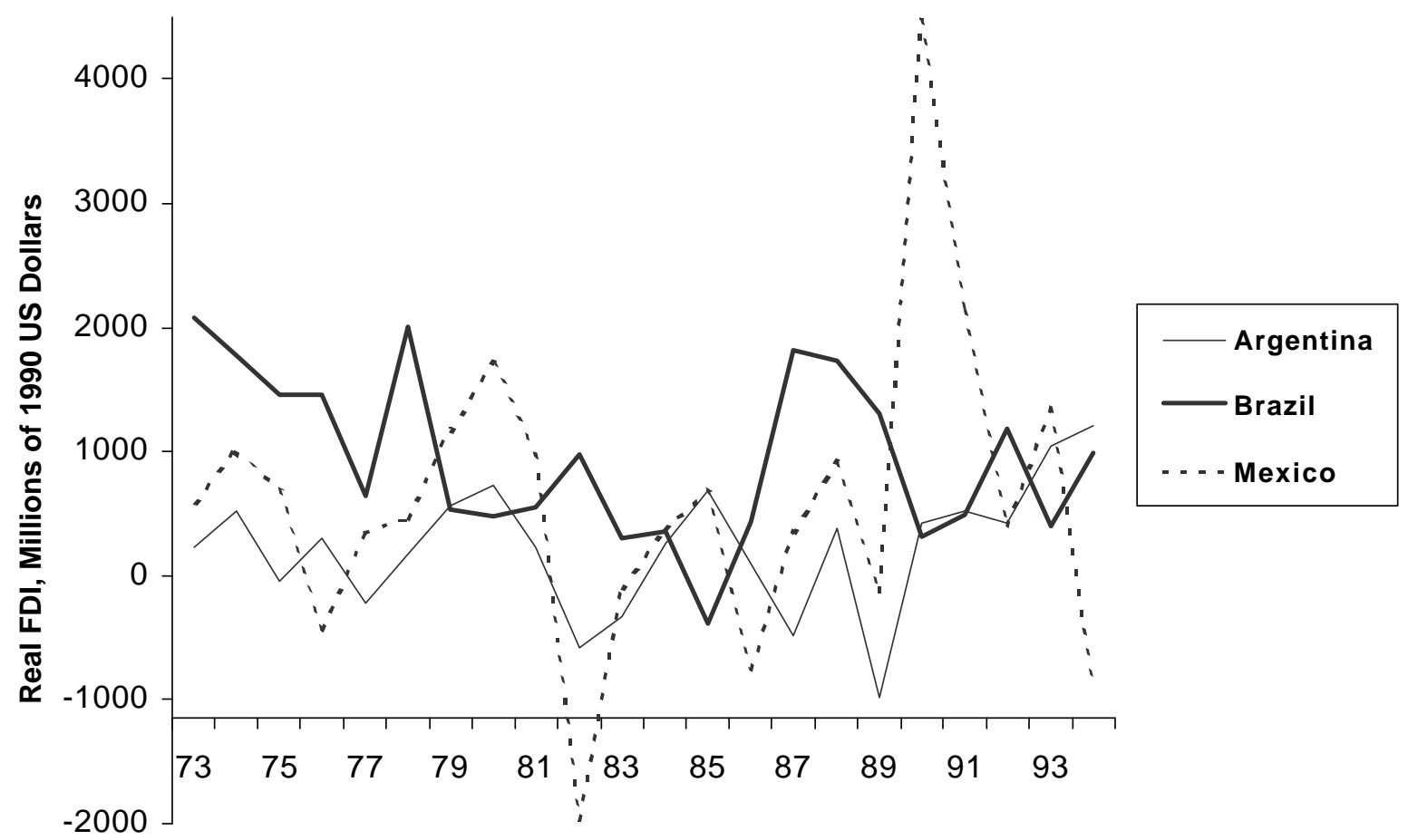

*Source: BEA statistics on US direct investment position abroad. Constructed as the sum over all manufacturing and nonmanufacturing industries in the sample of the the deflated year-to-year change in direct investment position.

Latin American countries have been regular recipients of erratic U.S. outward investment flows over the past decades. As shown in Chart 1, U.S. FDI flows to various regions, including Latin America, and the Asia-Pacific area have been growing following a period of decline and stagnation in the early to mid 1980s. In general, FDI flows to Latin America account for about 13 percent of US FDI to the three major FDI recipient regions (Europe, Latin America, and Asia-Pacific). Within Latin America, the main recipient countries have been Brazil, Mexico, and Argentina, respectively accounting for approximately 45, 30 and 10 percent of the region's inflows from the United States over 
the two decades we examine. Chart 2 shows the considerable volatility of these flows across countries and over time. ${ }^{6}$

For our purposes, it also is informative to consider the sectoral composition of these flows. Table 1 shows that, across Latin America, Chemical \& Allied Products, Transportation Equipment, and Other Manufacturing have been regular recipients of investment capital owned by the United States. Recent years have been marked by an explosion of funds into Food \& Kindred Products and Banking and Finance sectors. This latter phenomenon is driven by flows into Chile, where Banking and Finance ${ }^{7}$ sectors are the entry point for most foreign capital. We do not know the extent to which this capital is channeled to local manufacturing or non-manufacturing industries.

\section{Table 1: Sectoral Composition of US FDI in Latin America over Selected Intervals*}

Millions of 1990 US Dollars

\begin{tabular}{|c|c|c|c|c|}
\hline & 1973-1977 & 1978-1982 & 1983-1988 & 1989-1994 \\
\hline Food \& Kindred Products & 635.13 & 1124.66 & 20.17 & 3974.41 \\
\hline Primary \& Fabricated Metals & 731.62 & 700.22 & 421.33 & -351.34 \\
\hline Chemical \& Allied Products & 1895.85 & 1523.33 & 926.00 & 2138.16 \\
\hline Machinery, Except Electrical & 421.75 & 1068.73 & 705.54 & -544.61 \\
\hline Electric \& Electronic Equipment & & 399.96 & 129.08 & 729.99 \\
\hline Transportation Equipment & 591.59 & 1350.41 & 1028.49 & 1573.77 \\
\hline Other Manufacturing & 2042.42 & 1895.85 & 1077.82 & 1349.30 \\
\hline Wholesale Trade & 941.52 & 599.76 & -220.04 & 1854.25 \\
\hline Banking \& Other Finance & 1377.24 & 1729.70 & 1005.22 & 3701.49 \\
\hline Services & & & 800.40 & 699.44 \\
\hline Other Non-manufacturing & 319.41 & 115.44 & -262.33 & 2937.35 \\
\hline
\end{tabular}

*Source: FDI numbers were obtained by summing the deflated year-to-year changes in BEA directinvestment-position-abroad data across for all eight countries in the sample.

\footnotetext{
${ }^{6}$ Despite the apparent volatility of these flows, Lipsey (1999) still finds that foreign direct investment is the most stable source of international capital for emerging market economies.

7 "Finance" is used here in place of the FIRE acronym, representing Finance, Insurance and Real Estate.
} 
The pattern of exports, imports and capital flows for the individual sectors of each country is shown in detail in the panels of Table 2. In Argentina, the favored sectors for FDI have been Food \& Kindred Products, Wholesale Trade, and Banking and Finance. In Brazil, foreign capital inflows have been directed toward a broad range of industries, a substantial portion of which fall into Chemicals, Transportation, and the Other Manufacturing (residual) categories. In Mexico, the Food, Chemicals, and Transportation sectors have been important attractors of foreign capital. In Chile it is less transparent which sectors ultimately receive FDI from the United States: capital inflows land in Finance, Banking and "Other" non-manufacturing industries. These sectors presumably reinvest some significant resources across manufacturing, but the data do not provide specifics on the ultimate sectoral beneficiaries of these foreign long-term investments.

Table 2 also presents evidence on the sectoral pattern of exports and imports of the manufacturing sectors of each Latin American country. Non-electrical Machinery shipments make up a significant portion of Latin American exports to the United States, even though all countries in the sample are net importers in this sector. The Chemical sectors have been important, and Transportation has grown considerably in importance over the past decade. In Ecuador and Venezuela, manufacturing products are a small share of the overall export revenues. Table 2 also makes evident the varied the importance of manufacturing trade relative to total trade across the Latin American countries.

Since our theoretical section emphasized that sectoral net trade positions, i.e. whether a sector is a net importer or net exporter, are relevant for understanding the implications of FDI, it is useful to consider this directly for the sectors of the Latin American economies. Table 3 provides a very general overview of sectoral net export position by country. For Venezuela and for Mexico, the "Other" Non-manufacturing sector contains a significant fraction of the economy's exports because of heavy reliance on the petroleum sector. Most of the remaining manufacturing sectors are net importers. The remaining Latin American countries are large net exporters of Food \& Kindred Products. All countries in the sample except Colombia, Ecuador, and Venezuela also are large net exporters of Primary \& Fabricated Metals . 
Table 2: Sectoral Composition of Trade and FDI by Country, 1972-1994

\begin{tabular}{|c|c|c|c|c|c|c|c|c|c|c|c|}
\hline \multirow{2}{*}{\begin{tabular}{|l|} 
\\
Country
\end{tabular}} & \multicolumn{7}{|c|}{ Manufacturing } & \multicolumn{4}{|c|}{ Non-Manufacturing } \\
\hline & \begin{tabular}{|l|} 
Food \& \\
Kindred \\
Products
\end{tabular} & \begin{tabular}{|l|} 
Chemicals \\
\&Allied \\
Products
\end{tabular} & \begin{tabular}{|l|} 
Primary \& \\
Fabricated \\
Metals
\end{tabular} & \begin{tabular}{|l} 
Machinery, \\
Except \\
Electrical
\end{tabular} & \begin{tabular}{|l|} 
Electric \& \\
Electronic \\
Equipment
\end{tabular} & \begin{tabular}{|l|} 
Transportation \\
Equipment
\end{tabular} & \begin{tabular}{|l|} 
Other \\
Manufacturing
\end{tabular} & \begin{tabular}{l|l} 
Wholesale \\
Trade
\end{tabular} & $\begin{array}{l}\text { Banking \& } \\
\text { Finance }\end{array}$ & Services & $\begin{array}{l}\text { Other Non- } \\
\text { Manufacturing } \\
\text { Industries }\end{array}$ \\
\hline \multicolumn{12}{|c|}{ Sectoral FDI from the US, as a fraction of total FDI from the US, by recipient country } \\
\hline Argentina & 0.16 & 0.10 & -0.01 & 0.05 & 0.00 & 0.05 & 0.10 & 0.13 & 0.30 & 0.03 & 0.06 \\
\hline Brazil & 0.08 & 0.12 & 0.05 & 0.07 & 0.03 & 0.10 & 0.20 & 0.03 & 0.18 & 0.05 & 0.02 \\
\hline Ecuador & 0.23 & 0.08 & -0.05 & 0.00 & 0.07 & 0.01 & 0.01 & 0.12 & 0.02 & -0.01 & 0.00 \\
\hline Mexico & 0.20 & \begin{tabular}{|l|}
0.18 \\
\end{tabular} & 0.03 & 0.01 & 0.04 & 0.15 & 0.10 & 0.10 & 0.13 & 0.03 & 0.15 \\
\hline Peru & -0.13 & 0.08 & 0.01 & -0.01 & 0.02 & \begin{tabular}{l|}
-0.02 \\
\end{tabular} & \begin{tabular}{|l|}
-0.07 \\
\end{tabular} & 0.14 & 0.09 & 0.00 & -0.11 \\
\hline Venezuela & 0.20 & 0.19 & 0.03 & -0.05 & 0.00 & 0.15 & 0.16 & 0.04 & -0.01 & -0.05 & 0.03 \\
\hline \multicolumn{8}{|c|}{ Sectoral exports to the US, as a fraction of total manufacturing exports to the US, by source country } & \multicolumn{4}{|c|}{$\begin{array}{l}\text { Manufacturing exports to the US as a } \\
\text { fraction of total exports to the US }\end{array}$} \\
\hline Argentina & 0.01 & 0.23 & 0.06 & 0.30 & 0.12 & 0.13 & 0.14 & \multicolumn{4}{|c|}{0.75} \\
\hline Mexico & 0.05 & 0.10 & 0.11 & 0.19 & 0.20 & 0.14 & 0.21 & \multicolumn{4}{|c|}{0.86} \\
\hline Peru & 0.11 & 0.19 & 0.07 & 0.32 & 0.07 & 0.13 & 0.10 & \multicolumn{4}{|c|}{0.50} \\
\hline Venezuela & 0.07 & 0.14 & 0.07 & 0.32 & 0.10 & 0.16 & 0.15 & \multicolumn{4}{|c|}{0.04} \\
\hline \multicolumn{9}{|c|}{ Sectoral imports from the US, as a fraction of total manufacturing imports from the US, by destination country } & \multicolumn{3}{|c|}{$\begin{array}{l}\text { Manufacturing imports from the US as a } \\
\text { fraction of total imports from the US }\end{array}$} \\
\hline Argentina & 0.40 & 0.07 & 0.18 & 0.03 & 0.01 & 0.02 & 0.29 & \multicolumn{4}{|c|}{0.89} \\
\hline Brazil & 0.21 & 0.04 & 0.16 & 0.08 & 0.05 & 0.11 & 0.34 & \multicolumn{4}{|c|}{0.78} \\
\hline Chile & 0.11 & 0.07 & 0.70 & 0.00 & 0.00 & 0.00 & 0.11 & \multicolumn{4}{|c|}{0.83} \\
\hline Colombia & 0.22 & 0.04 & 0.05 & 0.00 & 0.01 & 0.00 & 0.67 & \multicolumn{4}{|c|}{0.85} \\
\hline Ecuador & 0.76 & 0.01 & 0.04 & 0.00 & 0.00 & 0.00 & 0.19 & \multicolumn{4}{|c|}{0.91} \\
\hline Mexico & 0.05 & 0.03 & 0.10 & 0.08 & 0.34 & 0.17 & 0.23 & \multicolumn{4}{|c|}{0.92} \\
\hline Peru & 0.23 & 0.01 & 0.55 & 0.00 & 0.00 & 0.00 & 0.21 & \multicolumn{4}{|c|}{0.81} \\
\hline Venezuela & 0.05 & 0.11 & 0.57 & 0.03 & 0.01 & 0.06 & 0.16 & \multicolumn{4}{|c|}{0.81} \\
\hline
\end{tabular}


Table 3: Net Export Position for the Entire Sample Period (1972-1994)*

Millions of 1990 US Dollars

\begin{tabular}{|l|r|r|r|l|l|l|l|}
\hline & $\begin{array}{l}\text { Food \& } \\
\text { Kindred } \\
\text { Products }\end{array}$ & $\begin{array}{l}\text { Primary \& } \\
\text { Fabricated } \\
\text { Metals }\end{array}$ & $\begin{array}{l}\text { lhemicals \& } \\
\text { Allied } \\
\text { Products }\end{array}$ & $\begin{array}{l}\text { Machinery, } \\
\text { Except } \\
\text { Electrical }\end{array}$ & $\begin{array}{l}\text { Electric \& } \\
\text { Electronic } \\
\text { Equipment }\end{array}$ & $\begin{array}{l}\text { Transportation } \\
\text { Equipment }\end{array}$ & $\begin{array}{l}\text { Other } \\
\text { Manufacturing }\end{array}$ \\
\hline Argentina & 6781 & 1101 & -6806 & -9851 & -4193 & -4295 & 369 \\
\hline Brazil & 19998 & 10706 & -19191 & -15426 & -5834 & -4977 & 24296 \\
\hline Chile & 479 & 7598 & -3559 & -7842 & -2218 & -3198 & -2489 \\
\hline Colombia & 142 & -1321 & -8595 & -9875 & -2881 & -6120 & 643 \\
\hline Ecuador & 1066 & -880 & -2769 & -4554 & -1331 & -1923 & -2504 \\
\hline Mexico & -5645 & -12019 & -26726 & -46452 & 20830 & -2833 & -11861 \\
\hline Peru & 672 & 5033 & -3369 & -5924 & -1278 & -2382 & -13128 \\
\hline Venezuela & -5526 & -2489 & -11618 & -27139 & -8204 & 581 \\
\hline
\end{tabular}

* Numbers were obtained by summing over all years (for each industry) the value of US imports from a given country minus the value of US exports to that country.

B. Testing for FDI Effects on Trade: The two-factor-model presented in Section II demonstrates that direct investment into a particular sector raises its level of output. The overall volume of trade in goods produced by that sector will increase if that sector was initially a net exporter and it will decrease if that sector was initially a net importer. Conversely, direct investment to one sector is expected to draw labor away from other sectors and cause output in those sectors to contract. In this case, the volume of trade in goods produced by the contracting sector decreases if that sector initially had a trade surplus and increases if that sector initially had a trade deficit. Direct investment to a sector is predicted to increase its net export balance, ceteris paribus, and to decrease the net export balance of other sectors, by drawing resources away from these other sectors. We test these predictions of the theory using sectoral trade and investment data from seven Latin American countries. ${ }^{8}$

The basic time-series cross-section regression equation for a particular Latin American country takes the form

$$
\begin{aligned}
\Delta n e t X_{t}^{i}= & \alpha_{o}^{i}+\alpha_{1} \Delta \text { USrealGDP } P_{t, t-1}+\alpha_{2} \Delta \text { OwnrealGDP } P_{t, t-1}+\alpha_{3} \Delta R E R_{t, t-1} \\
& +\alpha_{4} \text { OwnFDI }_{t-1, t-2}^{i}+\alpha_{5} \text { OtherFDI }_{t-1, t-2}^{i}+u_{t}^{i}+v_{t}
\end{aligned}
$$


where $\Delta n e t X_{\mathrm{t}}^{i}$ represents the change in net exports of sector $i . \Delta U$ SrealGDP represents the change in real GDP of the United States; $\triangle O$ wnrealGDP represents the change in the real GDP of the Latin American country; $\triangle R E R$ represents the change in the real exchange rate of that country (with a positive value representing a dollar appreciation); OwnFDI represents the direct investment flow from the United States into sector $i$; OtherFDI ${ }^{i}$ represents the direct investment flow to all manufacturing sectors other than sector $i, \alpha_{0}^{i}$ is a fixed-effects dummy variable on levels of net exports for manufacturing sector $i$; and subscripts on these variables refer to time periods.

The subscript $t, t-1$ reflects the inclusion in the regressions of both a current and a lagged term, while the subscript $t-1, t-2$ reflects the inclusion of both a one-period and a two-period lag. Thus the coefficients $\alpha_{i}$ represent two coefficients, one on the contemporaneous variable and one on the lagged variable or, in the case of the FDI variables, one on the variable lagged one period and one on the variable lagged two periods. The model presented above suggests that the sum of coefficients represented by the coefficient $\alpha_{4}$ is positive while the sum of the coefficients represented by the coefficient $\alpha_{5}$ is negative. Standard trade models suggest that the sum of coefficients represented by each of the coefficient $\alpha_{1}, \alpha_{2}$ and $\alpha_{3}$ are positive. ${ }^{9}$

The results from the regression analysis can be combined with information on net trade flows to address the question of whether direct investment promotes or diminishes trade. A positive and significant coefficient on the change in own-sector direct investment $\alpha_{4}$ indicates that direct investment promotes trade if the country's bilateral trade balance with the United States is negative. This case, corresponding to Mundell's analysis, is one in which direct investment decreases overall trade by reducing exports from the United States to the particular country (assuming that the negative overall trade statistic does not mask a shift from a long-standing negative position to a larger positive position which has only occurred for a few years in the sample period). Conversely, the

\footnotetext{
${ }^{8}$ Because of missing data, we exclude Ecuador from this part of our empirical analysis.

${ }^{9}$ The change in the real exchange rate, the change in domestic income and the change in United States income are aggregate regressors in that they have the same value across all sectors in any particular year. Aggregate regressors of this type preclude the use of time dummy variables and require the adjustment of the standard errors, as shown by Kloeck (1981).
} 
combination of a positive and significant value of $\alpha_{4}$ or with a positive trade balance for a country indicates that direct investment to that country promotes trade by expanding an already-existing trade surplus. This corresponds to the situation in the Ricardian model discussed above. A negative and significant value of the coefficient on other-sector direct investment, $\alpha_{5}$, combined with a national bilateral trade deficit with the United States suggests that direct investment promotes the volume of trade, all else equal, by increasing trade flows from the United States. Conversely, when a country has a bilateral trade surplus with the United States, direct investment to one sector which diminishes net exports of other sectors serves to reduce the overall volume of trade, all else equal.

The error term in the regression equation (8) consists of an error specific to the particular industry for the particular year, $u_{i t}$, and an error common to all industries in the country for that year, $v_{t}$. The presence of the common error term, $v_{t}$, can typically be addressed using a fixed-effects dummy variable or, equivalently, subtracting the yearspecific mean value from all the variables in the regression. In this case, however, we have regressors common to all industries in any particular year, such as the change in the real exchange rate, the change in domestic income and the change in United States income. Thus we cannot subtract out the year-specific mean value since these aggregate regressors are common across all cross-sectional units. Instead, we use an iterative procedure which estimates the variance of $v_{t}$ and then adjusts the variance-covariance matrix in an appropriate manner (see Kloeck 1981 for a discussion of this problem and its resolution). 
C. Empirical Results: Summary results for regressions using the specification in equation (8) are presented in the two panels of Table 4. Each of these panels represents sets of regressions, where the sets are differentiated by the amount of information included in the other-sector FDI variable. In regressions summarized in Panel A, each country's regression contains terms for own industry FDI and for FDI elsewhere in manufacturing. ${ }^{10}$

Table 4: Regression Results for Direct Investment Coefficients: Summed Two-Period Effects

\begin{tabular}{|c|c|c|c|c|c|c|c|}
\hline & Argentina & Brazil & Chile & Colombia & Mexico & Peru & Venezuela \\
\hline \multicolumn{8}{|l|}{ Panel A } \\
\hline Own Industry FDI & $\begin{aligned} 0.591 * * \\
(0.272)\end{aligned}$ & $\begin{array}{l}-0.193 \\
(0.138)\end{array}$ & $\begin{array}{c}0.217 \\
(0.876)\end{array}$ & $\begin{array}{l}0.679 \\
(0.485)\end{array}$ & $\begin{array}{c}0.358 \\
(0.299)\end{array}$ & $\begin{array}{l}-0.611 \\
(1.56)\end{array}$ & $\begin{array}{l}-0.151 \\
(0.309)\end{array}$ \\
\hline $\begin{array}{l}\text { FDI to other } \\
\text { manufacturing } \\
\text { Industries }\end{array}$ & $\begin{array}{l}-0.023 \\
(0.044)\end{array}$ & $\begin{array}{c}0.045 \\
(0.046)\end{array}$ & $\begin{array}{l}-0.076 \\
(0.28)\end{array}$ & $\begin{array}{l}0.24 * * \\
(0.113)\end{array}$ & $\begin{array}{l}-.222 * * \\
(0.095)\end{array}$ & $\begin{array}{l}-0.406 \\
(0.709)\end{array}$ & $\begin{array}{l}-0.179 \\
(0.153)\end{array}$ \\
\hline $\begin{array}{l}\text { Number of } \\
\text { Observations }\end{array}$ & 96 & 133 & 66 & 90 & 125 & 83 & 110 \\
\hline \multicolumn{8}{|l|}{ Panel B } \\
\hline Own Industry FDI & $\begin{array}{c}0.533 \\
(0.363)\end{array}$ & $\begin{array}{l}-0.242 * \\
(0.138)\end{array}$ & $\begin{array}{c}0.546 \\
(1.083)\end{array}$ & $\begin{array}{l}-0.072 \\
(0.778)\end{array}$ & $\begin{array}{l}0.519 \\
(0.4)\end{array}$ & $\begin{array}{l}-0.859 \\
(1.657)\end{array}$ & $\begin{array}{l}-0.716^{*} \\
(0.378)\end{array}$ \\
\hline $\begin{array}{l}\text { FDI to other } \\
\text { manufacturing } \\
\text { Industries }\end{array}$ & $\begin{array}{c}0.01 \\
(0.057)\end{array}$ & $\begin{array}{c}0.027 \\
(0.041)\end{array}$ & $\begin{array}{l}-0.225 \\
(0.412)\end{array}$ & $\begin{array}{c}0.129 \\
(0.228)\end{array}$ & $\begin{array}{c}0.29 \\
(0.232)\end{array}$ & $\begin{array}{l}-0.326 \\
(0.758)\end{array}$ & $\begin{array}{c}-0.487 * * \\
(0.242)\end{array}$ \\
\hline $\begin{array}{l}\text { FDI to Wholesale } \\
\text { and Retail Trade }\end{array}$ & $\begin{array}{l}-0.424 \\
(0.332)\end{array}$ & $\begin{array}{l}.803 * * * \\
(0.234)\end{array}$ & $\begin{array}{c}0.178 \\
(0.933)\end{array}$ & $\begin{array}{c}-13.36^{* *} \\
(5.538)\end{array}$ & $\begin{array}{r}-1.49 * * \\
(0.716)\end{array}$ & $\begin{array}{c}0.592 \\
(1.515)\end{array}$ & $\begin{array}{l}3.438 \\
(2.138)\end{array}$ \\
\hline $\begin{array}{l}\text { FDI to Banking, } \\
\text { Finance, } \\
\text { Insurance, and } \\
\text { Real Estate }\end{array}$ & $\begin{array}{c}0.153 \\
(0.256)\end{array}$ & $\begin{array}{l}-0.043 \\
(0.071)\end{array}$ & $\begin{array}{c}0.068 \\
(0.178)\end{array}$ & $\begin{array}{c}0.934 \\
(0.937)\end{array}$ & $\begin{array}{l}-1.151 \\
(0.818)\end{array}$ & $\begin{array}{l}-0.131 \\
(1.468)\end{array}$ & $\begin{array}{l}1.259^{*} \\
(0.666)\end{array}$ \\
\hline $\begin{array}{l}\text { Number of } \\
\text { Observations }\end{array}$ & 76 & 133 & 66 & 69 & 110 & 83 & 91 \\
\hline
\end{tabular}

Standard Errors in parentheses. *,**, and $* * *$ indicate significance at the 10, 5, and 1 percent levels respectively.

\footnotetext{
${ }^{10}$ Appendix Table1 provides estimates of the individual regression coefficients that form the basis of the numbers reported in the body of the text and in Table 4, Panel A. Appendix Table 2 feeds in Panel B.
} 
Panel A results suggest that a significant role is played by own-sector FDI in promoting net exports in Argentina. Own-sector direct investment promotes net exports in Mexico with a one-year lag, as shown in the complete results presented in Appendix Table 1. By summing across the rows for Argentina and Mexico in Table 3, we observe that both countries have a bilateral trade deficit with the United States with respect to manufactured goods. Thus for these countries, which represent two of the three largest United States trading partners in Latin America, there is evidence that own-sector direct investment has the marginal effect of reducing the volume of bilateral trade in a way consistent with Mundell's analysis.

The results in Panel A also suggest that other-sector direct investment tends to reduce net exports in Mexico and increase net exports in Columbia. This mitigates, but does not reverse, the conclusion that direct investment to Mexico tends to reduce the volume of trade since the sum of the coefficients on own-sector direct investment, 0.358 , is greater, in absolute value, of the sum of the coefficients on other-sector direct investment, -0.222 . For Colombia, the marginal effect of direct investment is to promote exports and, therefore, reduce the volume of bilateral trade in manufacturing goods since both the own-sector and other-sector coefficients are positive.

In Panel B, we allow for direct investment into non-manufacturing sectors to also affect the output and, therefore, the trade of manufacturing sectors. There are two possible channels through which these implications may arise. The first channel is that associated with labor reallocation across sectors, as emphasized in the model presented above. The second channel recognizes the role of the output of one sector as an input to the production of other sectors. In this way, direct investment to, for instance, the financial sector may serve to increase output in manufacturing sectors, as the expanded finance sector serves the needs of the manufacturing sectors. Likewise, expansion of the wholesale trade sector may enable manufacturing sectors to expand output for domestic sales, or it may lead to expanded opportunities for imports. Given the tendency toward manufacturing sector trade deficits with the United States, a positive coefficient on nonmanufacturing direct investment implies that this type of direct investment causes a decline in the volume of bilateral trade with the United States while a negative coefficient means 
that this type of direct investment serves to increase the volume of bilateral trade, all else equal.

Table 4, Panel B, presents summed two-year net export effects derived from regressions which include both own-sector and other-manufacturing-sector direct investment, plus two other sectoral direct investment measures: direct investment in the Finance, Banking and Real Estate sectors and direct investment in the Wholesale and Retail Trade sector. These results show that foreign direct investment into the Banking, Finance and Real Estate sectors, as well as to the Wholesale and Retail Trade sector, have a significant effect on cross-sectional sectoral trade in a number of countries although the direction of this effect differs across countries. Direct investment to the Wholesale and Retail Trade sector has a positive and significant effect on trade by manufacturing sectors in Brazil and, with a one-period lag only, in Venezuela. Conversely, direct investment to this sector has a negative and significant effect on trade by manufacturing sectors in Colombia and Mexico. The effect of direct investment into the Banking, Finance and Real Estate sectors on trade by manufacturing sectors is significant for Argentina, Mexico and Venezuela. In Argentina and Mexico, the initial effect is to promote trade while the effect after one year is to diminish trade. In Venezuela, direct investment to the Finance, Banking and Real Estate sectors also significantly increases trade at the ninety- percent level of confidence, with a significant coefficient on the two-year lag at the ninety-five percent level of confidence.

A comparison of the results in Panel A and Panel B shows that the inclusion of direct investment from these non-manufacturing sectors also affects the pattern of significance on the own-sector and other-manufacturing sector direct investment variables. But some of these differences arise due to differences in the samples available when including the non-manufacturing direct investment measures. The sample sizes for the results in Panel B are smaller than those in Panel A. Using the restricted samples employed in Panel B, but running regressions of the form presented in Panel A, coefficients on direct investment variables which are reported as significant in Panel A for Argentina, Mexico (on own-sector direct investment) and Venezuela are no longer significant. 
Our second and final group of regressions were run on data grouped by industry, instead of by country. The regression specification employed is analogous to the one used in the country regressions, and incorporates appropriate modifications. Specifically, since the industry regressions include as the left-hand-side variable the net export data for one industry and several countries, the industry dummies are discarded in favor of country dummies. These regressions do not require the type of correction to the variancecovariance matrix discussed above since regressors such as the real exchange rate and income are not common to all cross-sectional units in a particular year.

Table 5 displays regression results for the cumulative effects of lagged independent variables. The results for own industry FDI are less illuminating for these regressions than those obtained in the country runs; own industry FDI affects trade significantly only in the case of the "Other Manufacturing" (residual) category, where FDI flows stifle net exports after one year while stimulating them after two, the cumulative effect being a decrease in net exports.

Stronger evidence is provided for the role of FDI into other industries in drawing resources away from Primary and Fabricated Metals. In addition, FDI to industries other than Electric \& Electronic Equipment sector had a significant negative effect on trade in that industry after one year; the same coefficient was negative but insignificant after two years, causing the cumulative effect of both coefficients to be insignificant. The regression results for the Electric \& Electronic Equipment sector also provides evidence that banking and other types of financial FDI inflows stimulate net exports. 


\begin{tabular}{|c|c|c|c|c|c|c|c|}
\hline & $\begin{array}{l}\text { Food \& } \\
\text { Kindred } \\
\text { Products }\end{array}$ & $\begin{array}{l}\text { Primary \& } \\
\text { Fabricated } \\
\text { Metals }\end{array}$ & $\begin{array}{l}\text { Chemicals } \\
\text { \& Allied } \\
\text { Products }\end{array}$ & $\begin{array}{l}\text { Machinery, } \\
\text { Except } \\
\text { Electrical }\end{array}$ & $\begin{array}{l}\text { Electric \& } \\
\text { Electronic } \\
\text { Equipment }\end{array}$ & $\begin{array}{l}\text { Transportation } \\
\text { Equipment }\end{array}$ & $\begin{array}{l}\text { Other } \\
\text { Manufacturing }\end{array}$ \\
\hline \multicolumn{8}{|l|}{ Panel A } \\
\hline $\begin{array}{l}\text { Own Industry } \\
\text { FDI }\end{array}$ & $\begin{array}{l}-0.333 \\
(0.206)\end{array}$ & $\begin{array}{c}0.471 \\
(0.457)\end{array}$ & $\begin{array}{l}-0.238 \\
(0.17)\end{array}$ & $\begin{array}{c}0.140 \\
(0.262)\end{array}$ & $\begin{array}{l}-0.373 \\
(0.796\end{array}$ & $\begin{array}{c}0.113 \\
(0.317)\end{array}$ & $\begin{array}{l}-0.63 * \\
(0.333)\end{array}$ \\
\hline $\begin{array}{l}\text { FDI to other } \\
\text { manufacturing } \\
\text { Industries }\end{array}$ & $\begin{array}{c}0.026 \\
(0.047)\end{array}$ & $\begin{array}{c}-0.158^{* * *} \\
(0.079)\end{array}$ & $\begin{array}{l}0.026 \\
(0.043)\end{array}$ & $\begin{array}{l}-0.077 \\
(0.085)\end{array}$ & $\begin{array}{l}-0.031 \\
(0.121)\end{array}$ & $\begin{array}{l}-0.108 \\
(0.117)\end{array}$ & $\begin{array}{c}0.037 \\
(0.107)\end{array}$ \\
\hline $\begin{array}{l}\text { Number of } \\
\text { Observations }\end{array}$ & 143 & 107 & 148 & 135 & 77 & 91 & 73 \\
\hline \multicolumn{8}{|l|}{ Panel B } \\
\hline $\begin{array}{l}\text { Own Industry } \\
\text { FDI }\end{array}$ & $\begin{array}{l}-0.202 \\
(0.371)\end{array}$ & $\begin{array}{c}0.155 \\
(0.531)\end{array}$ & $\begin{array}{l}-0.385 \\
(0.242)\end{array}$ & $\begin{array}{c}0.371 \\
(0.285)\end{array}$ & $\begin{array}{c}1.051 \\
(0.776)\end{array}$ & $\begin{array}{c}0.057 \\
(0.459)\end{array}$ & $\begin{array}{l}-0.808^{*} \\
(0.426)\end{array}$ \\
\hline $\begin{array}{l}\text { FDI to other } \\
\text { manufacturing } \\
\text { Industries }\end{array}$ & $\begin{array}{c}0.06 \\
(0.062)\end{array}$ & $\begin{array}{c}0.025 \\
(0.122)\end{array}$ & $\begin{array}{c}0.071 \\
(0.062)\end{array}$ & $\begin{array}{c}0.07 \\
(0.12)\end{array}$ & $\begin{array}{l}-0.239 * \\
(0.139)\end{array}$ & $\begin{array}{l}-0.247 \\
(0.177)\end{array}$ & $\begin{array}{l}0.107 \\
(0.15)\end{array}$ \\
\hline $\begin{array}{l}\text { FDI to } \\
\text { Wholesale and } \\
\text { Retail Trade }\end{array}$ & $\begin{array}{c}0.205 \\
(0.239)\end{array}$ & $\begin{array}{c}0.008 \\
(0.402)\end{array}$ & $\begin{array}{l}0.242 \\
(0.24)\end{array}$ & $\begin{array}{l}-0.403 \\
(0.469)\end{array}$ & $\begin{array}{c}0.644 \\
(0.413)\end{array}$ & $\begin{array}{c}0.898 \\
(0.638)\end{array}$ & $\begin{array}{l}0.016 \\
(0.357)\end{array}$ \\
\hline $\begin{array}{l}\text { FDI to } \\
\text { Banking, and } \\
\text { F.I.R.E. }\end{array}$ & $\begin{array}{c}0.039 \\
(0.167)\end{array}$ & $\begin{array}{c}0.198 \\
(0.271)\end{array}$ & $\begin{array}{c}0.164 \\
(0.132)\end{array}$ & $\begin{array}{l}0.039 \\
(.30)\end{array}$ & $\begin{array}{l}.567 * * * \\
(0.197)\end{array}$ & $\begin{array}{c}0.524 \\
(.0426)\end{array}$ & $\begin{array}{l}0.048 \\
(0.21)\end{array}$ \\
\hline $\begin{array}{l}\text { Number of } \\
\text { Observations }\end{array}$ & 121 & 89 & 124 & 114 & 72 & 75 & 68 \\
\hline
\end{tabular}

Standard Errors in parentheses. *, **, and *** indicate significance at the 10, 5, and 1 percent levels respectively. 


\section{Concluding Remarks}

The increasing importance of foreign direct investment in the world economy calls for theoretical and empirical investigations into the manner in which FDI affects the linkages among countries. A central question concerning FDI is whether it increases or decreases the volume of trade. Mundell's early contribution showed a channel through which investment substitutes for trade, while later theoretical research presents cases where trade and investment may serve as substitutes or complements.

Our theoretical model highlights some basic aspects of the different channels through which foreign direct investment can alter the sectoral composition of capital and labor in an economy. We provide the results of a detailed examination of the linkages between FDI into particular sectors of Latin American economies and the net exports of those and other manufacturing sectors. Our analysis indicates that some FDI tends to expand manufacturing trade, while other FDI clearly reduces the volumes of manufacturing trade. In Latin American countries, FDI from the United States can lead to significant, and varied shifts in the composition of activity in many countries across many manufacturing sectors.

Given the mixed pattern linkages, it is reasonable to ask whether the Latin American results are expected to generalize to other partnering relationships among countries around the world. We conjecture that bilateral sectoral investment and trade flows-- other than those between the United States and Latin America-- may reveal stronger relationships than the mixed picture presented here. For example, in our earlier work (Goldberg and Klein 1998) we present evidence of relatively strong and significant effects of overall bilateral direct investment from Japan on the overall bilateral trade of Southeast Asian countries. The weakest results in that earlier paper were for the effects of United States direct investment on the trade of Latin American countries. Those results did not use data disaggregated by sectors and, unfortunately, data availability precluded us from studying the effects of sectoral direct investment from Japan. While the Latin American results that we have presented do not provide strong evidence that capital flows systematically and generally expand on contract trade flows, the experiences of other important regions around the world could also provide important lessons. 


\section{References}

Collins, William J., Kevin H. O'Rourke and Jeffrey G. Williamson, "Were Trade and Factor Mobility Substitutes in History?" N.B.E.R. Working Paper Number 6059, June 1997.

Froot, Kenneth and Jeremy Stein, "Exchange Rates and Foreign Direct Investment: An Imperfect Capital Markets Approach," Quarterly Journal of Economics, vol. 106, 1991, pp. 1191-1217.

Goldberg, Linda S. and Michael W. Klein, 1998. "Foreign Direct Investment, Trade and Real Exchange Rate Linkages in Developing Countries," in Reuven Glick ed. Managing Capital Flows and Exchange Rates: Lessons from the Pacific Basin (Cambridge University Press).

Jones, Ronald W., "International Capital Movements and the Theory of Tariffs and Trade," Quarterly Journal of Economics, volume 81, February 1967, pp. 1-38.

Kemp, Murray C., "The Gain from International Trade and Investment: A NeoHeckscher-Ohlin Approach," American Economic Review, volume 61, September 1966, pp. 788-809.

Klein, Michael W. and Eric Rosengren, "The Real Exchange Rate and Foreign Direct Investment in the United States: Relative Wealth vs. Relative Wage Effects," Journal of International Economics, vol. 36, 1994, pp. 373-389.

Kloeke, Teun, 1981. "OLS Estimation in a Model Where A Microvariable is Explained by Aggregates and Contemporaneous Disturbances are Equicorrelated," Econometrica vol 49 no 1 (January) pp. 205-207.

Lipsey, Robert E., 1999. "The Role of Foreign Direct Investment in International Capital Flows.” NBER working paper 7094 (April).

Markusen, James R., "Factor Movements and Commodity Trade as Complements," Journal of International Economics, volume 13, 1983, pp. 341-356.

Markusen, James R., "The Boundaries of Multinational Enterprises and the Theory of International Trade" Journal of Economic Perspectives Spring 1995 vol. 9 no. 2, pp. 169189.

Markusen, James R. and Lars E.O. Svensson, "Trade in Goods and Factors with International Differences in Technology," International Economic Review, volume 26, 1985, pp. 175-192. 
Mundell, Robert, "International Trade and Factor Mobility," American Economic Review, volume 47, June 1957, pp. 321-335.

Purvis, Douglas D., "Technology, Trade and Factor Mobility," Economic Journal, volume 82, 1972, pp. 991-999.

Schmitz, Andrew and Peter Helmberger, "Factor Mobility and International Trade: The Case of Complementarity," American Economic Review, volume 60, 1970, pp. 761-767.

Svensson, Lars E.O., "Factor Trade and Goods Trade," Journal of International Economics, volume 16, 1984, pp. 365-378.

Wong, Kar-yiu, “Are International Trade and Factor Mobility Substitutes?" Journal of International Economics, volume 21, no. 1/2, August 1986, pp. 25-44. 
</ref_section> 


\begin{tabular}{|c|c|c|c|c|c|c|c|}
\hline \multicolumn{8}{|c|}{ Appendix Table 1: Regression Results for Direct Investment Coefficients (Panel A)* } \\
\hline & Argentina & Brazil & Chile & Colombia & Mexico & Peru & Venezuela \\
\hline $\begin{array}{l}\text { Own Industry FDI (One } \\
\text { Period Lag) }\end{array}$ & $\begin{array}{c}0.193 \\
(0.180)\end{array}$ & $\begin{array}{c}0.031 \\
(0.096)\end{array}$ & $\begin{array}{r}-0.614 \\
(0.583)\end{array}$ & $\begin{array}{c}0.271 \\
(0.331)\end{array}$ & $\begin{array}{l}-0.191 \\
(0.164)\end{array}$ & $\begin{array}{l}-1.134 \\
(1.045)\end{array}$ & $\begin{array}{l}-0.122 \\
(0.225)\end{array}$ \\
\hline $\begin{array}{l}\text { Own Industry FDI (Two } \\
\text { Period Lag) }\end{array}$ & $\begin{array}{l}0.398^{*} \\
(0.203)\end{array}$ & $\begin{array}{c}-0.224 * * \\
(0.097)\end{array}$ & $\begin{array}{c}0.831 \\
(0.670)\end{array}$ & $\begin{array}{l}0.408 \\
(0.340)\end{array}$ & $\begin{array}{l}0.548^{* *} \\
(0.249)\end{array}$ & $\begin{array}{c}0.524 \\
(0.971)\end{array}$ & $\begin{array}{l}-0.289 \\
(0.178)\end{array}$ \\
\hline $\begin{array}{l}\text { FDI to all other } \\
\text { Manufacturing Industries } \\
\text { (One Period Lag) }\end{array}$ & $\begin{array}{l}-0.025 \\
(0.034)\end{array}$ & $\begin{array}{c}0.047 \\
(0.040)\end{array}$ & $\begin{array}{l}-0.168 \\
(0.187)\end{array}$ & $\begin{array}{l}0.078 \\
(0.06)\end{array}$ & $\begin{array}{l}-.152 * * \\
(0.062)\end{array}$ & $\begin{array}{l}-0.271 \\
(0.428)\end{array}$ & $\begin{array}{l}-0.232 * \\
(0.127)\end{array}$ \\
\hline $\begin{array}{l}\text { FDI to all other } \\
\text { Manufacturing } \\
\text { Industries } \\
\text { (Two Period Lag) }\end{array}$ & $\begin{array}{c}0.002 \\
(0.035)\end{array}$ & $\begin{array}{l}-0.002 \\
(0.039)\end{array}$ & $\begin{array}{l}0.092 \\
(0.27)\end{array}$ & $\begin{array}{l}0.162 * * \\
(0.078)\end{array}$ & $\begin{array}{c}-0.07 \\
(0.056)\end{array}$ & $\begin{array}{l}-0.135 \\
(0.416)\end{array}$ & $\begin{array}{c}0.053 \\
(0.091)\end{array}$ \\
\hline Real Exchange Rate & $\begin{array}{l}0.746^{* *} \\
(0.311)\end{array}$ & $\begin{array}{l}2.202^{*} \\
(1.179)\end{array}$ & $\begin{array}{c}-4.37 * * * \\
(1.289)\end{array}$ & $\begin{array}{c}5.182 * * * \\
(1.658)\end{array}$ & $\begin{array}{l}16.9 * * * \\
(3.814)\end{array}$ & $\begin{array}{c}0.236 \\
(0.306)\end{array}$ & $\begin{array}{l}-2.979 \\
(1.95)\end{array}$ \\
\hline $\begin{array}{l}\text { Real Exchange Rate } \\
\text { (One Period Lag) }\end{array}$ & $\begin{array}{c}0.099 \\
(0.433)\end{array}$ & $\begin{array}{c}4.896 * * * \\
(1.284)\end{array}$ & $\begin{array}{c}0.871 \\
(0.976)\end{array}$ & $\begin{array}{l}-2.793 \\
(2.002)\end{array}$ & $\begin{array}{l}-1.451 \\
(4.148)\end{array}$ & $\begin{array}{c}0.122 \\
(0.322)\end{array}$ & $\begin{array}{c}0.223 \\
(2.058)\end{array}$ \\
\hline US Real GDP & $\begin{array}{c}1.82 \mathrm{e}-4 \\
(1.13 \mathrm{e}-4)\end{array}$ & $\begin{array}{c}6.0 \mathrm{e}-4 * * * \\
(2.0 \mathrm{e}-4)\end{array}$ & $\begin{array}{c}1.75 \mathrm{e}-4 \\
(2.07 \mathrm{e}-4)\end{array}$ & $\begin{array}{l}2.05 \mathrm{e}-4^{* *} \\
(8.94 \mathrm{e}-5)\end{array}$ & $\begin{array}{c}1.5 \mathrm{e}-4 \\
(5.8 \mathrm{e}-4)\end{array}$ & $\begin{array}{c}5.78 \mathrm{e}-5 \\
(1.43 \mathrm{e}-4)\end{array}$ & $\begin{array}{c}6.11 \mathrm{e}-5 \\
(1.44 \mathrm{e}-4)\end{array}$ \\
\hline $\begin{array}{l}\text { US Real GDP (One } \\
\text { Period Lag) }\end{array}$ & $\begin{array}{l}-1.64 \mathrm{e}-4 \\
(1.07 \mathrm{e}-4)\end{array}$ & $\begin{array}{c}1.41 \mathrm{e}-5 \\
(2.32 \mathrm{e}-4)\end{array}$ & $\begin{array}{c}7.36 \mathrm{e}-5 \\
(1.29 \mathrm{e}-4)\end{array}$ & $\begin{array}{c}1.05 \mathrm{e}-4 \\
(9.77 \mathrm{e}-5)\end{array}$ & $\begin{array}{l}-5.52 \mathrm{e}-4 \\
(5.2 \mathrm{e}-4)\end{array}$ & $\begin{array}{c}4.12 \mathrm{e}-5 \\
(1.36 \mathrm{e}-4)\end{array}$ & $\begin{array}{l}-7.97 e-5 \\
(1.54 \mathrm{e}-4)\end{array}$ \\
\hline Local Real GDP** & $\begin{array}{l}-.012 * * * \\
(0.003)\end{array}$ & $\begin{array}{l}* *-157.1 \\
(65.6)\end{array}$ & $\begin{array}{c}-1.3 \mathrm{e}- \\
4 * * \\
(5.13 \mathrm{e}-5)\end{array}$ & $\begin{array}{c}-8.6 \mathrm{e}- \\
5 * * * \\
(3.15 \mathrm{e}-5)\end{array}$ & $\begin{array}{l}-0.004 \\
(0.003)\end{array}$ & $\begin{array}{l}-0.034 \\
(0.027)\end{array}$ & $\begin{array}{r}-0.001 * * * \\
(1.84 \mathrm{e}-4)\end{array}$ \\
\hline $\begin{array}{l}\text { Local Real GDP** } \\
\text { (One Period Lag) }\end{array}$ & $\begin{array}{l}-0.003 \\
(0.003)\end{array}$ & $\begin{array}{c}4.2 \\
(51.8)\end{array}$ & $\begin{array}{c}6.4 \mathrm{e}-5 \\
(4.4 \mathrm{e}-5)\end{array}$ & $\begin{array}{c}7.7 \mathrm{e}-5 \\
(4.34 \mathrm{e}-5)\end{array}$ & $\begin{array}{l}-0.001 \\
(0.003)\end{array}$ & $\begin{array}{l}-0.011 \\
(0.033)\end{array}$ & $\begin{array}{c}2.7 \mathrm{e}-4 \\
(2.61 \mathrm{e}-4)\end{array}$ \\
\hline Number of Observations & 96 & 133 & 66 & 90 & 125 & 83 & 110 \\
\hline
\end{tabular}

Standard Errors in parentheses. *, **, and *** indicate significance at the 10,5, and 1 percent levels respectively.

**Millions of local currency units. 


\begin{tabular}{|c|c|c|c|c|c|c|c|}
\hline Appendix Table 2: & ssion $\mathrm{F}$ & ts for & t Inv & ent $\mathrm{Cos}$ & ents $(1$ & B)* & \\
\hline & Argentina & Brazil & Chile & Colombia & Mexico & Peru & Venezuela \\
\hline $\begin{array}{l}\text { Own Industry FDI (One } \\
\text { Period Lag) }\end{array}$ & $\begin{array}{c}0.079 \\
(0.251)\end{array}$ & $\begin{array}{l}-0.001 \\
(0.095)\end{array}$ & $\begin{array}{l}-1.241 * \\
(0.738)\end{array}$ & $\begin{array}{c}0.29 \\
(0.49)\end{array}$ & $\begin{array}{l}-0.183 \\
(0.196)\end{array}$ & $\begin{array}{l}-1.217 \\
(1.092)\end{array}$ & $\begin{array}{l}-0.351 \\
(0.259)\end{array}$ \\
\hline $\begin{array}{l}\text { Own Industry FDI (Two } \\
\text { Period Lag) }\end{array}$ & $\begin{array}{l}0.455^{*} \\
(0.274)\end{array}$ & $\begin{array}{c}-0.242 * * \\
(0.096)\end{array}$ & $\begin{array}{l}1.997 * * \\
(0.864)\end{array}$ & $\begin{array}{c}-0.14 \\
(0.571)\end{array}$ & $\begin{array}{l}0.702 * * \\
(0.316)\end{array}$ & $\begin{array}{c}0.358 \\
(1.055)\end{array}$ & $\begin{array}{l}-0.365 \\
(0.287)\end{array}$ \\
\hline $\begin{array}{l}\text { FDI to all other } \\
\text { Manufacturing } \\
\text { Industries } \\
\text { (One Period Lag) }\end{array}$ & $\begin{array}{l}-0.001 \\
(0.034)\end{array}$ & $\begin{array}{c}0.02 \\
(0.035)\end{array}$ & $\begin{array}{c}-0.717 * * \\
(0.325)\end{array}$ & $\begin{array}{c}0.061 \\
(0.103)\end{array}$ & $\begin{array}{l}-0.162 \\
(0.115)\end{array}$ & $\begin{array}{l}-0.269 \\
(0.465)\end{array}$ & $\begin{array}{l}-0.244 \\
(0.163)\end{array}$ \\
\hline $\begin{array}{l}\text { FDI to all other } \\
\text { Manufacturing } \\
\text { Industries } \\
\text { (Two Period Lag) }\end{array}$ & $\begin{array}{c}0.012 \\
(0.049)\end{array}$ & $\begin{array}{c}0.007 \\
(0.032)\end{array}$ & $\begin{array}{l}0.597^{*} \\
(0.336)\end{array}$ & $\begin{array}{c}0.133 \\
(0.171)\end{array}$ & $\begin{array}{c}0.453 * * * \\
(0.171)\end{array}$ & $\begin{array}{l}-0.057 \\
(0.457)\end{array}$ & $\begin{array}{l}-0.243 \\
(0.248)\end{array}$ \\
\hline $\begin{array}{l}\text { FDI to Wholesale Trade } \\
\text { Industries } \\
\text { (One Period Lag) }\end{array}$ & $\begin{array}{l}-0.278 \\
(0.216)\end{array}$ & $\begin{array}{l}0.387 * * * \\
(0.132)\end{array}$ & $\begin{array}{l}-0.36 \\
(0.458)\end{array}$ & $\begin{array}{l}-8.76 * * \\
(3.988)\end{array}$ & $\begin{array}{l}-0.105 \\
(0.414)\end{array}$ & $\begin{array}{c}0.437 \\
(1.247)\end{array}$ & $\begin{array}{c}2.301 * * * \\
(0.764)\end{array}$ \\
\hline $\begin{array}{l}\text { FDI to Wholesale Trade } \\
\text { Industries } \\
\text { (Two Period Lag) }\end{array}$ & $\begin{array}{l}-0.147 \\
(0.172)\end{array}$ & $\begin{array}{c}0.415^{* * *} \\
(0.132)\end{array}$ & $\begin{array}{c}0.803 \\
(0.642)\end{array}$ & $\begin{array}{l}-3.25^{*} \\
(1.868)\end{array}$ & $\begin{array}{c}-1.343 * * * \\
(0.474)\end{array}$ & $\begin{array}{c}0.156 \\
(1.054)\end{array}$ & $\begin{array}{l}1.148 \\
(1.632)\end{array}$ \\
\hline $\begin{array}{l}\text { FDI to Banking, F.I.R.E. } \\
\text { (One Period Lag) }\end{array}$ & $\begin{array}{l}0.972 * * \\
(0.396)\end{array}$ & $\begin{array}{c}0.05 \\
(0.06)\end{array}$ & $\begin{array}{l}-0.104 \\
(0.169)\end{array}$ & $\begin{array}{l}0.696 \\
(0.442)\end{array}$ & $\begin{array}{c}0.617 * * * \\
(0.225)\end{array}$ & $\begin{array}{l}-0.415 \\
(0.942)\end{array}$ & $\begin{array}{l}-0.46 \\
(0.581)\end{array}$ \\
\hline $\begin{array}{l}\text { FDI to Banking, F.I.R.E. } \\
\text { (Two Period Lag) }\end{array}$ & $\begin{array}{c}-0.819 * * \\
(0.410) \\
\end{array}$ & $\begin{array}{l}-0.934 \\
(0.061) \\
\end{array}$ & $\begin{array}{c}0.152 \\
(0.104) \\
\end{array}$ & $\begin{array}{l}-0.016 \\
(0.648) \\
\end{array}$ & $\begin{array}{l}-1.768^{*} \\
(0.937) \\
\end{array}$ & $\begin{array}{c}0.284 \\
(1.157) \\
\end{array}$ & $\begin{array}{l}1.719 * * \\
(0.792) \\
\end{array}$ \\
\hline Real Exchange Rate & $\begin{array}{l}-1.368 \\
(0.928)\end{array}$ & $\begin{array}{c}2.776 * * * \\
(0.952)\end{array}$ & $\begin{array}{l}-7.1 * * * \\
(1.545)\end{array}$ & $\begin{array}{l}8.452 * * * \\
(1.882)\end{array}$ & $\begin{array}{l}20.118 * * * \\
(4.66)\end{array}$ & $\begin{array}{c}0.191 \\
(0.339)\end{array}$ & $\begin{array}{l}7.716 \\
(5.092)\end{array}$ \\
\hline $\begin{array}{l}\text { Real Exchange Rate } \\
\text { (One Period Lag) }\end{array}$ & $\begin{array}{c}1.111 \\
(0.897)\end{array}$ & $\begin{array}{c}4.003 * * * \\
(1.027)\end{array}$ & $\begin{array}{c}0.575 \\
(0.888)\end{array}$ & $\begin{array}{l}-31.50^{* *} \\
(12.693)\end{array}$ & $\begin{array}{l}-5.602 \\
(5.976)\end{array}$ & $\begin{array}{c}0.109 \\
(0.354)\end{array}$ & $\begin{array}{l}7.511 \\
(6.889)\end{array}$ \\
\hline US Real GDP & $\begin{array}{c}3.29 \mathrm{e}-4^{* *} \\
(1.29 \mathrm{e}-4)\end{array}$ & $\begin{array}{l}0.001 * * * \\
(1.94 \mathrm{e}-4)\end{array}$ & $\begin{array}{c}5.4 \mathrm{e}-4 * * * \\
(2.1 \mathrm{e}-4)\end{array}$ & $\begin{array}{l}-3.84 \mathrm{e}-5 \\
(2.04 \mathrm{e}-4)\end{array}$ & $\begin{array}{c}7.61 \mathrm{e}-5 \\
(5.65 \mathrm{e}-4)\end{array}$ & $\begin{array}{l}8.65 \mathrm{e}-5 \\
(1.6 \mathrm{e}-4)\end{array}$ & $\begin{array}{c}8.64 \mathrm{e}-4 \\
(6.44 \mathrm{e}-4)\end{array}$ \\
\hline $\begin{array}{l}\text { US Real GDP (One } \\
\text { Period Lag) }\end{array}$ & $\begin{array}{c}-4.6 \mathrm{e}- \\
4 * * * \\
(1.21 \mathrm{e}-4) \\
\end{array}$ & $\begin{array}{l}4.31 \mathrm{e}-4^{*} \\
(2.34 \mathrm{e}-4)\end{array}$ & $\begin{array}{c}1.41-4 \\
(1.37-4)\end{array}$ & $\begin{array}{l}-4.43 \mathrm{e}-4 \\
(3.72 \mathrm{e}-4)\end{array}$ & $\begin{array}{c}7.76 \mathrm{e}-6 \\
(5.18 \mathrm{e}-4)\end{array}$ & $\begin{array}{l}4.19 \mathrm{e}-5 \\
(1.7 \mathrm{e}-4)\end{array}$ & $\begin{array}{l}-1.03-\mathrm{e} 4 \\
(3.93 \mathrm{e}-4)\end{array}$ \\
\hline Local Real GDP** & $\begin{array}{c}-0.028 * * * \\
(0.007)\end{array}$ & $\begin{array}{l}-274 . \\
* * * \\
(65.3)\end{array}$ & $\begin{array}{c}-2.5 \mathrm{e}- \\
4 * * * \\
(6.28 \mathrm{e}-5)\end{array}$ & $\begin{array}{l}-2.48 \mathrm{e}-5 \\
(3.67 \mathrm{e}-5)\end{array}$ & $\begin{array}{l}-0.005^{*} \\
(0.003)\end{array}$ & $\begin{array}{l}-0.032 \\
(0.036)\end{array}$ & $\begin{array}{r}-0.002 * * * \\
(5.85 \mathrm{e}-4)\end{array}$ \\
\hline $\begin{array}{l}\text { Local Real GDP } \\
\text { (One Period Lag) }\end{array}$ & $\begin{array}{l}-0.003 \\
(0.005)\end{array}$ & $\begin{array}{l}-81.3 \\
(50.6)\end{array}$ & $\begin{array}{l}1.34 \mathrm{e}-4 * * \\
(5.52 \mathrm{e}-5)\end{array}$ & $\begin{array}{l}3.11 \mathrm{e}-4 * * \\
(1.35 \mathrm{e}-4)\end{array}$ & $\begin{array}{l}-0.004 \\
(0.003)\end{array}$ & $\begin{array}{l}-0.019 \\
(0.044)\end{array}$ & $\begin{array}{l}-5.04 \mathrm{e}-4 \\
(9.94 \mathrm{e}-4)\end{array}$ \\
\hline Number of Observations & 76 & 133 & 66 & 69 & 110 & 83 & 91 \\
\hline
\end{tabular}

Standard Errors in parentheses. *, **, and *** indicate significance at the 10,5, and 1 percent levels respectively. 


\begin{tabular}{|c|c|c|c|c|c|c|c|}
\hline \multicolumn{8}{|c|}{ Appendix Table 3: Regression Results for Sectoral Direct Investment Coefficients (Panel A)* } \\
\hline & $\begin{array}{l}\text { Food \& } \\
\text { Kindred } \\
\text { Products }\end{array}$ & $\begin{array}{l}\text { Primary \& } \\
\text { Fabricated } \\
\text { Metals }\end{array}$ & $\begin{array}{l}\text { Chemicals } \\
\& \text { Allied } \\
\text { Products }\end{array}$ & $\begin{array}{l}\text { Machiner } \\
\text { y Except } \\
\text { Electrical }\end{array}$ & $\begin{array}{l}\text { Electric \& } \\
\text { Electronic } \\
\text { Equipment }\end{array}$ & $\begin{array}{l}\text { Transport } \\
\text { Equipment }\end{array}$ & $\begin{array}{l}\text { Other } \\
\text { Manufacturing }\end{array}$ \\
\hline $\begin{array}{l}\text { Own Industry FDI (One } \\
\text { Period Lag) }\end{array}$ & $\begin{array}{l}-0.117 \\
(0.12)\end{array}$ & $\begin{array}{l}-0.228 \\
(0.295)\end{array}$ & $\begin{array}{l}-0.055 \\
(0.115)\end{array}$ & $\begin{array}{l}-0.068 \\
(0.188)\end{array}$ & $\begin{array}{l}-0.692 \\
(0.507)\end{array}$ & $\begin{array}{l}-0.153 \\
(0.181)\end{array}$ & $\begin{array}{l}-0.339 \\
(0.225)\end{array}$ \\
\hline $\begin{array}{l}\text { Own Industry FDI (Two } \\
\text { Period Lag) }\end{array}$ & $\begin{array}{l}-0.216 \\
(0.196)\end{array}$ & $\begin{array}{l}0.699 * * \\
(0.327)\end{array}$ & $\begin{array}{l}-0.183 \\
(0.124)\end{array}$ & $\begin{array}{l}0.208 \\
(0.186)\end{array}$ & $\begin{array}{c}0.319 \\
(0.511)\end{array}$ & $\begin{array}{c}0.266 \\
(0.243)\end{array}$ & $\begin{array}{l}-0.290 \\
(0.225)\end{array}$ \\
\hline $\begin{array}{l}\text { FDI to all other } \\
\text { Manufacturing Industries } \\
\text { (One Period Lag) }\end{array}$ & $\begin{array}{l}-0.039 \\
(0.031)\end{array}$ & $\begin{array}{c}-0.197 * * * \\
(.0567)\end{array}$ & $\begin{array}{l}0.006 \\
(0.03)\end{array}$ & $\begin{array}{l}-0.185 \\
(0.061)\end{array}$ & $\begin{array}{l}-0.074 \\
(0.086)\end{array}$ & $\begin{array}{l}-0.118 \\
(0.081)\end{array}$ & $\begin{array}{l}-0.142 * \\
(0.073)\end{array}$ \\
\hline $\begin{array}{l}\text { FDI to all other } \\
\text { Manufacturing } \\
\text { Industries } \\
\text { (Two Period Lag) }\end{array}$ & $\begin{array}{l}0.065 \\
(0.034)\end{array}$ & $\begin{array}{c}0.039 \\
(0.053)\end{array}$ & $\begin{array}{c}0.02 \\
(0.029)\end{array}$ & $\begin{array}{l}0.108 \\
(0.062)\end{array}$ & $\begin{array}{c}0.043 \\
(0.083)\end{array}$ & $\begin{array}{c}0.01 \\
(0.085)\end{array}$ & $\begin{array}{l}0.179 * * \\
(0.078)\end{array}$ \\
\hline Real Exchange Rate & $\begin{array}{c}0.56 \\
(0.675)\end{array}$ & $\begin{array}{l}3.721 * * * \\
(1.321)\end{array}$ & $\begin{array}{l}0.931 * \\
(0.502)\end{array}$ & $\begin{array}{l}2.99 * * * \\
(1.09)\end{array}$ & $\begin{array}{c}0.951 \\
(1.055)\end{array}$ & $\begin{array}{l}3.049 * \\
(1.769)\end{array}$ & $\begin{array}{l}5.685 * * * \\
(1.454)\end{array}$ \\
\hline $\begin{array}{l}\text { Real Exchange Rate } \\
\text { (One Period Lag) }\end{array}$ & $\begin{array}{c}0.202 \\
(0.702)\end{array}$ & $\begin{array}{c}0.723 \\
(1.395)\end{array}$ & $\begin{array}{c}0.794 \\
(0.525)\end{array}$ & $\begin{array}{l}1.255 \\
(1.934)\end{array}$ & $\begin{array}{l}-0.069 \\
(1.081)\end{array}$ & $\begin{array}{c}2.321 \\
(1.867)\end{array}$ & $\begin{array}{l}1.19 \\
(1.416)\end{array}$ \\
\hline US Real GDP & $\begin{array}{l}1.89 \mathrm{e}-4^{*} \\
(1.13 \mathrm{e}-4)\end{array}$ & $\begin{array}{l}4.98 \mathrm{e}-4 * \\
(2.57 \mathrm{e}-4)\end{array}$ & $\begin{array}{l}8.94 \mathrm{e}-5 \\
(1.52 \mathrm{e}-4)\end{array}$ & $\begin{array}{l}(7.08-7) \\
(3.28 \mathrm{e}-4)\end{array}$ & $\begin{array}{c}1.46 \mathrm{e}-4 \\
(2.43 \mathrm{e}-4)\end{array}$ & $\begin{array}{l}-1.07 \mathrm{e}-4 \\
(4.28 \mathrm{e}-4)\end{array}$ & $\begin{array}{l}5.38 \mathrm{e}-4 * * \\
(2.73 \mathrm{e}-4)\end{array}$ \\
\hline $\begin{array}{l}\text { US Real GDP } \\
\text { (One Period Lag) }\end{array}$ & $\begin{array}{c}1.32 \mathrm{e}-4 \\
(1.08 \mathrm{e}-4)\end{array}$ & $\begin{array}{l}-3.49 \mathrm{e}-4 \\
2.52 \mathrm{e}-4\end{array}$ & $\begin{array}{c}3.3 \mathrm{e}-4 \\
(1.47 \mathrm{e}-4)\end{array}$ & $\begin{array}{l}-1.51 \mathrm{e}-4 \\
(3.15 \mathrm{e}-4)\end{array}$ & $\begin{array}{l}-1.62 \mathrm{e}-4 \\
(2.51 \mathrm{e}-4)\end{array}$ & $\begin{array}{c}3.23 \mathrm{e}-4 \\
(4.32 \mathrm{e}-4)\end{array}$ & $\begin{array}{l}-2.85 e-4 \\
(2.43 e-4)\end{array}$ \\
\hline Local Real GDP** & $\begin{array}{l}-4.44 e-5 \\
(6.74 e-5)\end{array}$ & $\begin{array}{c}8.35 \mathrm{e}-6 \\
(1.15 \mathrm{e}-4)\end{array}$ & $\begin{array}{c}(4 \mathrm{e}-5) \\
(5.07 \mathrm{e}-5)\end{array}$ & $\begin{array}{c}-7.1 \mathrm{e}-5 \\
(1.11 \mathrm{e}-4)\end{array}$ & $\begin{array}{l}-8.77 e-5 \\
(1.73 e-4)\end{array}$ & $\begin{array}{l}-4.01 \mathrm{e}-4 \\
(3.64 \mathrm{e}-4)\end{array}$ & $\begin{array}{l}-2.78 \mathrm{e}-5 \\
(1.54 \mathrm{e}-4)\end{array}$ \\
\hline $\begin{array}{l}\text { Local Real GDP } \\
\text { (One Period Lag) }\end{array}$ & $\begin{array}{l}(7.11 \mathrm{e}-6) \\
(6.77 \mathrm{e}-5)\end{array}$ & $\begin{array}{l}9.23 e-5 \\
(1.3 e-4)\end{array}$ & $\begin{array}{c}6.05 e-5 \\
(5.68 \mathrm{e}-5)\end{array}$ & $\begin{array}{c}3.11 \mathrm{e}-5 \\
(1.16 \mathrm{e}-4)\end{array}$ & $\begin{array}{c}1.52 \mathrm{e}-5 \\
(1.98 \mathrm{e}-4)\end{array}$ & $\begin{array}{l}-1.33 e-4 \\
(3.66 e-4)\end{array}$ & $\begin{array}{c}5.04 \mathrm{e}-6 \\
(1.84 \mathrm{e}-4)\end{array}$ \\
\hline Number of Observations & 143 & 107 & 148 & 135 & 77 & 91 & 73 \\
\hline
\end{tabular}

Standard Errors in parentheses. *,**, and *** indicate significance at the 10, 5, and 1 percent levels respectively. 


\begin{tabular}{|c|c|c|c|c|c|c|c|}
\hline \multicolumn{8}{|c|}{ Appendix Table 4: Regression Results for Sectoral Direct Investment Coefficients (Panel B)* } \\
\hline & $\begin{array}{l}\text { Food \& } \\
\text { Kindred } \\
\text { Products }\end{array}$ & $\begin{array}{l}\text { Primary \& } \\
\text { Fabricated } \\
\text { Metals }\end{array}$ & $\begin{array}{l}\text { Chemicals } \\
\& \text { Allied } \\
\text { Products }\end{array}$ & $\begin{array}{l}\text { Machiner } \\
\text { y Except } \\
\text { Electrical }\end{array}$ & $\begin{array}{l}\text { Electric \& } \\
\text { Electronic } \\
\text { Equipment }\end{array}$ & $\begin{array}{l}\text { Transport. } \\
\text { Equipment }\end{array}$ & $\begin{array}{l}\text { Other } \\
\text { Manufacturing }\end{array}$ \\
\hline $\begin{array}{l}\text { Own Industry FDI } \\
\text { (One Period Lag) }\end{array}$ & $\begin{array}{l}-0.276 \\
(0.202)\end{array}$ & $\begin{array}{l}-0.229 \\
(0.353)\end{array}$ & $\begin{array}{l}-0.096 \\
(0.162)\end{array}$ & $\begin{array}{l}0.351^{*} \\
(0.204)\end{array}$ & $\begin{array}{c}0.207 \\
(0.492)\end{array}$ & $\begin{array}{l}-0.083 \\
(0.298)\end{array}$ & $\begin{array}{r}-0.463 * \\
(0.272)\end{array}$ \\
\hline $\begin{array}{l}\text { Own Industry FDI } \\
\text { (Two Period Lag) }\end{array}$ & $\begin{array}{c}0.074 \\
(0.277)\end{array}$ & $\begin{array}{c}0.384 \\
(0.409)\end{array}$ & $\begin{array}{l}-0.289 * \\
(0.171)\end{array}$ & $\begin{array}{c}0.019 \\
(0.201)\end{array}$ & $\begin{array}{l}0.845^{*} \\
(0.479)\end{array}$ & $\begin{array}{c}0.141 \\
(0.291)\end{array}$ & $\begin{array}{c}-0.3445 \\
(0.270)\end{array}$ \\
\hline $\begin{array}{l}\text { FDI to all other } \\
\text { Manufacturing } \\
\text { Industries } \\
\text { (One Period Lag) }\end{array}$ & $\begin{array}{c}0.021 \\
(0.046)\end{array}$ & $\begin{array}{l}-0.16^{*} \\
(0.09)\end{array}$ & $\begin{array}{c}0.043 \\
(0.046)\end{array}$ & $\begin{array}{l}-0.193 \\
(0.089)\end{array}$ & $\begin{array}{c}-0.178^{* *} \\
(0.09)\end{array}$ & $\begin{array}{l}-0.256^{*} \\
(0.136)\end{array}$ & $\begin{array}{l}-0.094 \\
(0.091)\end{array}$ \\
\hline $\begin{array}{l}\text { FDI to all other } \\
\text { Manufacturing } \\
\text { Industries } \\
\text { (Two Period Lag) }\end{array}$ & $\begin{array}{c}0.039 \\
(0.053)\end{array}$ & $\begin{array}{c}0.185^{* *} \\
(0.087)\end{array}$ & $\begin{array}{c}0.028 \\
(0.047)\end{array}$ & $\begin{array}{c}0.263 * * * \\
(0.092)\end{array}$ & $\begin{array}{c}-0.06 \\
(0.092)\end{array}$ & $\begin{array}{c}0.009 \\
(0.149)\end{array}$ & $\begin{array}{l}0.201 * \\
(0.107)\end{array}$ \\
\hline $\begin{array}{l}\text { FDI to Wholesale } \\
\text { Trade Industries } \\
\text { (One Period Lag) }\end{array}$ & $\begin{array}{c}0.023 \\
(0.157)\end{array}$ & $\begin{array}{l}-0.058 \\
(0.27)\end{array}$ & $\begin{array}{c}0.082 \\
(0.154)\end{array}$ & $\begin{array}{l}-1.008^{* * *} \\
(0.303)\end{array}$ & $\begin{array}{c}0.115 \\
(0.253)\end{array}$ & $\begin{array}{l}0.166^{*} \\
(0.404)\end{array}$ & $\begin{array}{l}-0.091 \\
(0.229)\end{array}$ \\
\hline $\begin{array}{l}\text { FDI to Wholesale } \\
\text { Trade Industries } \\
\text { (Two Period Lag) }\end{array}$ & $\begin{array}{c}0.181 \\
(0.153)\end{array}$ & $\begin{array}{l}.066 \\
(0.26)\end{array}$ & $\begin{array}{c}0.159 \\
(0.157)\end{array}$ & $\begin{array}{l}0.605^{* *} \\
(0.305)\end{array}$ & $\begin{array}{c}0.528 * * \\
(0.261)\end{array}$ & $\begin{array}{c}0.732 \\
(0.416)\end{array}$ & $\begin{array}{c}0.107 \\
(0.225)\end{array}$ \\
\hline $\begin{array}{l}\text { FDI to Banking, and } \\
\text { FIRE } \\
\text { (One Period Lag) }\end{array}$ & $\begin{array}{c}0.141 \\
(0.126)\end{array}$ & $\begin{array}{c}0.059 \\
(0.232)\end{array}$ & $\begin{array}{r}-0.004 \\
(0.09)\end{array}$ & $\begin{array}{l}0.056 \\
(0.23)\end{array}$ & $\begin{array}{c}0.602 * * * \\
(0.135)\end{array}$ & $\begin{array}{c}0.303 \\
(0.371)\end{array}$ & $\begin{array}{l}0.138 \\
(0.145)\end{array}$ \\
\hline $\begin{array}{l}\text { FDI to Banking, and } \\
\text { FIRE } \\
\text { (Two Period Lag) }\end{array}$ & $\begin{array}{l}-0.103 \\
(0.138)\end{array}$ & $\begin{array}{l}0.14 \\
(0.245)\end{array}$ & $\begin{array}{c}-0.16 \\
(0.124)\end{array}$ & $\begin{array}{l}-0.018 \\
(0.245)\end{array}$ & $\begin{array}{l}-0.035 \\
(0.196)\end{array}$ & $\begin{array}{c}0.221 \\
(0.396)\end{array}$ & $\begin{array}{l}-0.09 \\
(0.184)\end{array}$ \\
\hline Real Exchange Rate & $\begin{array}{c}0.489 \\
(0.8)\end{array}$ & $\begin{array}{l}2.999 * * \\
(1.444)\end{array}$ & $\begin{array}{c}0.867 \\
(0.572)\end{array}$ & $\begin{array}{l}2.34 * * \\
(1.095)\end{array}$ & $\begin{array}{c}0.514 \\
(0.903)\end{array}$ & $\begin{array}{l}3.173 \\
(2.066)\end{array}$ & $\begin{array}{r}5.249 * * * \\
(1.756)\end{array}$ \\
\hline $\begin{array}{l}\text { Real Exchange Rate } \\
\text { (One Period Lag) }\end{array}$ & $\begin{array}{c}0.394 \\
(0.867)\end{array}$ & $\begin{array}{c}0.236 \\
(1.589)\end{array}$ & $\begin{array}{l}1.03 \\
(0.61)\end{array}$ & $\begin{array}{c}0.436 \\
(1.216)\end{array}$ & $\begin{array}{c}0.396 \\
(0.928)\end{array}$ & $\begin{array}{c}1.834 \\
(2.266)\end{array}$ & $\begin{array}{c}0.922 \\
(1.667)\end{array}$ \\
\hline US Real GDP & $\begin{array}{l}3.1 \mathrm{e}-4 * * \\
(1.57 \mathrm{e}-4)\end{array}$ & $\begin{array}{l}6.4 \mathrm{e}-4 * * \\
(3.11 \mathrm{e}-4)\end{array}$ & $\begin{array}{l}-7.96 e-5 \\
(1.76 e-4)\end{array}$ & $\begin{array}{c}6.98 \mathrm{e}-5 \\
(3.37 \mathrm{e}-4)\end{array}$ & $\begin{array}{c}1.14 \mathrm{e}-4 \\
(2.28 \mathrm{e}-4)\end{array}$ & $\begin{array}{c}2.13 \mathrm{e}-4 \\
(5.39 \mathrm{e}-4)\end{array}$ & $\begin{array}{l}.5 .21 \mathrm{e}-4 \\
(3.42-4)\end{array}$ \\
\hline $\begin{array}{l}\text { US Real GDP (One } \\
\text { Period Lag) }\end{array}$ & $\begin{array}{c}1.04 \mathrm{e}-4 \\
(1.25 \mathrm{e}-4)\end{array}$ & $\begin{array}{l}-3.55 \mathrm{e}-4 \\
(2.81 \mathrm{e}-4)\end{array}$ & $\begin{array}{c}-3.46 \mathrm{e}- \\
4 * * \\
(1.63 \mathrm{e}-4) \\
\end{array}$ & $\begin{array}{c}6.61 \mathrm{e}-5 \\
(2.99 \mathrm{e}-4)\end{array}$ & $\begin{array}{l}-2.43 e-5 \\
(2.32-4)\end{array}$ & $\begin{array}{c}3.89 \mathrm{e}-4 \\
(5.06 \mathrm{e}-4)\end{array}$ & $\begin{array}{l}-2.83 \mathrm{e}-4 \\
(2.92 \mathrm{e}-4)\end{array}$ \\
\hline Local Real GDP** & $\begin{array}{l}-5.01 \mathrm{e}-5 \\
(7.49 \mathrm{e}-5)\end{array}$ & $\begin{array}{l}-5.42 \mathrm{e}-6 \\
(1.28 \mathrm{e}-4)\end{array}$ & $\begin{array}{l}-2.41 e-5 \\
(5.73 e-5)\end{array}$ & $\begin{array}{l}-8.85 \mathrm{e}-5 \\
(1.11 \mathrm{e}-4)\end{array}$ & $\begin{array}{l}-1 . .57 \mathrm{e}-4 \\
(1.53 \mathrm{e}-4)\end{array}$ & $\begin{array}{l}-3.66 \mathrm{e}-4 \\
(4.44 \mathrm{e}-4)\end{array}$ & $\begin{array}{c}1.11 \mathrm{e}-5 \\
(1.73 \mathrm{e}-4)\end{array}$ \\
\hline $\begin{array}{l}\text { Local Real GDP** } \\
\text { (One Period Lag) }\end{array}$ & $\begin{array}{c}-1.5 \mathrm{e}-5 \\
(7.45 \mathrm{e}-5)\end{array}$ & $\begin{array}{l}1.01 \mathrm{e}-4 \\
1.43 \mathrm{e}-4\end{array}$ & $\begin{array}{l}(5.11 \mathrm{e}-5) \\
(6.39 \mathrm{e}-5)\end{array}$ & $\begin{array}{l}4.37 \mathrm{e}-6 \\
(1.13 \mathrm{e}-4)\end{array}$ & $\begin{array}{l}-6.72 \mathrm{e}-5 \\
(1.74 \mathrm{e}-4)\end{array}$ & $\begin{array}{l}-2.01 \mathrm{e}-4 \\
(4.54 \mathrm{e}-4)\end{array}$ & $\begin{array}{l}-4.02 \mathrm{e}-5 \\
(2.14 \mathrm{e}-4)\end{array}$ \\
\hline $\begin{array}{l}\text { Number of } \\
\text { Observations }\end{array}$ & 121 & 89 & 124 & 114 & 72 & 75 & 68 \\
\hline
\end{tabular}

Standard Errors in parentheses. *,**, and *** indicate significance at the 10, 5, and 1 percent levels respectively. 